\title{
IMPACT OF WEED MANAGEMENT PRACTICES ON GRAPEVINE GROWTH, YIELD COMPONENTS, PLANT AND ARTHROPOD ABUNDANCE, AND CARABID SEED PREDATION IN PASO ROBLES VINEYARD
}

\author{
A Thesis \\ Presented to \\ the Faculty of California Polytechnic State University, \\ San Luis Obispo
} In Partial Fulfilment of the Requirements for the Degree Master of Science in Agriculture, with Specialization in Plant Protection Science by

Paolo Pontep Sanguankeo August 2009 
(C) 2009

Paolo Pontep Sanguankeo

ALL RIGHTS RESERVED 


\section{COMMITTEE MEMBERSHIP}

TITLE: $\quad$ Impact of weed management practices on grapevine growth, yield components, plant and arthropod abundance, and carabid seed predation in Paso Robles vineyard
AUTHOR:
Paolo Pontep Sanguankeo

DATE SUBMITTED:

September 2009

COMMITEE CHAIR: $\quad$ Michael Costello, $\mathrm{PhD}$

COMMITTEE MEMBER: $\quad$ David Headrick, PhD

COMMITTEE MEMBER: $\quad$ Steve Rein, $\mathrm{PhD}$ 


\begin{abstract}
Impact of weed management practices on grapevine growth, yield components, plant and arthropod abundance, and carabid seed predation in Paso Robles vineyard

Paolo Pontep Sanguankeo

In the Central Coast of California, USA, wine grape growers are making efforts to identify weed control practices that promote biodiversity in their vineyards while maintaining yields. A field study was conducted in Paso Robles, CA in 2006 and 2007 evaluating the effect on Zinfandel grape-vine growth and production, groundcover plant, and ground dwelling arthropod communities of five weed control practices: 1) flumioxazin, 2) simazine, 3) cultivation, 4) cover crop, and 5) untreated control.
\end{abstract}

The herbicide treatments had the lowest weed biomass followed by the cultivation, being approximately 10 and 2 times lower than the weed biomass of either the cover crop or untreated control treatments respectively. However, the differences in grape yield were not as evident. In 2006, a rainy year, the herbicides and cultivation treatments did not differ in grape yield, but the cover crop and untreated control had a reduction of approximately $20 \%$ compared with the other treatments. In 2007, a dry year, in comparison to the herbicide treatments, the grape yield reductions of cultivation were around $22 \%$, and of the cover crop and untreated control around $48 \%$. Although the cover crop reduced grape yield, it suppressed weed species considered important such as horseweed, panicle willowherb, scarlet pimpernel, and sowthistle. The cover crop, cultivation and untreated control had 4 to 50 times higher plant density and more than 15 times higher plant diversity compared to the herbicide treatments. The arthropod abundance differed among treatments only in 2007 being higher in the cover crop and untreated control. Also, there was a positive relationship 
between plant and arthropod diversity $\left(r^{2}=0.42, P=0.02\right.$ in $2006 ; r^{2}=0.64, P<0.001$ in 2007). Laboratory seed predation tests of the two most frequently captured carabid beetles, Calathus ruficollis and Tanystoma maculicolle, indicated their preferences for Brassica nigra and Capsella bursa-pastoris, which are considered common weed species in the region. Under field conditions, treatments with higher plant diversity and biomass favoured arthropod seed predation of these weeds, which was $20-40 \%$ in the cover crop and untreated control, doubling the predation observed in the herbicide treatments. The cultivation treatment balanced the benefits of promoting diversity while minimizing yield reductions due to weed competition.

Our data indicated that the critical period of weed competition for Zinfandel grape vines occurred during budbreak-bloom period. Also, it was concluded that vines can tolerate a certain amount of weed competition, and that properly timing one pass post-emergence control tactics (e.g. cultivation or POST herbicides) could provide the necessary level of control to obtain the desired yields. However, under limited soil moisture conditions, the use of PRE herbicides could prove important to maintain vine yield and vigor. The results also illustrate how weed management practices that promote higher plant diversity and density have the potential to yield ecological services within vineyards by favoring the diversity and activity of other organisms.

Keywords: herbicides, cover crop, cultivation, weed community, Vitis, grape yield, biodiversity, competition, seed predation 


\section{Acknowledgements}

We thank Jake Terrel, John Winstead, and Gallo Vineyards for their great support. We thank Bobby Arkle for his help with the NMS analysis. We thank James Labonte from Oregon

Department of Agriculture for help with updates on arthropod taxa. This research was funded by the Agricultural Research Initiative of the California State University System and the Central Coast Vineyard Team. 
LIST OF TABLES.....................................................viii-ix

LIST OF FIGURES ........................................................

\section{CHAPTER}

I. LITERATURE REVIEW ..........................................

II. INTRODUCTION .............................................. $7-9$

III. METHODS AND MATERIALS ...................................10-17

IV. $\quad$ RESULTS ....................................................... $18-25$

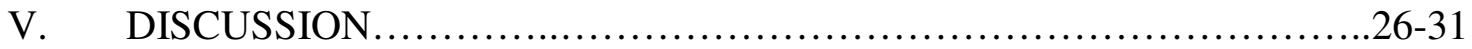

VI. CONCLUSION .......................................................... 32

VII. MANAGEMENT IMPLICATIONS ......................................

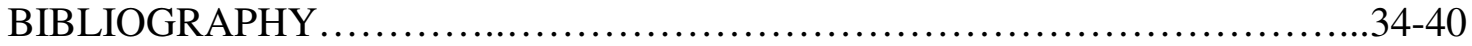

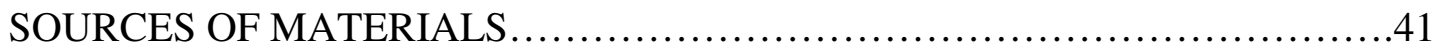

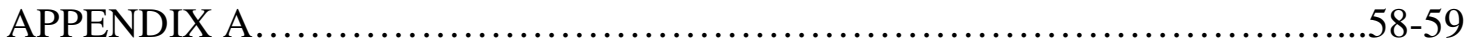




\section{LIST OF TABLES}

Table

Page

1. Species composition of the cover crop seeded in the berms in February of 2006 and 2007 in a Zinfandel vineyard in CA, USA. .....................42

2. Berm vegetation density including four functional groups in five vineyard weed management tactics in a Zinfandel vineyard in Central Coast California, USA

3. Berm vegetation biomass including four functional groups in five vineyard weed management tactics in a Zinfandel vineyard in Central Coast California, USA.

4. Percentage light interception of grapevine canopy and dormant grapevine cane weight biomass in five vineyard weed management tactics in a Zinfandel vineyard in Central Coast California, USA....

5. Grapevine fruit weight, cluster weight, number of cluster per vine, number of berry per cluster, and berry weight in five vineyard weed management tactics at a Zinfandel vineyard in Central Coast California, USA...

6. Grape juice parameters test results for Brix degree, Titratable Acidity, and $\mathrm{pH}$ in five vineyard weed management tactics at a Zinfandel vineyard in Central Coast California, USA.

7. Plant density, richness $(R)$, evenness $(E)$, and Shannon-Weiner diversity index $\left(H^{\prime}\right)$ in five weed management treatments in a Zinfandel vineyard in Central Coast California, USA, in 2006 and 2007.

8. Terrestrial arthropod activity-density, richness $(R)$, evenness $(E)$, and Shannon-Weiner diversity index $\left(H^{\prime}\right)$ in five weed management treatments in a Zinfandel vineyard in Central Coast California, USA in 2006 and 2007..51

9. Regression analyses of arthropod diversity $\left(H^{\prime}{ }_{\text {arthro }}\right)$ and plant density $\left(\mathrm{N}_{\text {plant }}\right)$ and diversity $\left(H^{\prime}\right.$ plant $)$ observed in a Zinfandel vineyard in Central Coast California, USA, in 2006 and 2007.

10. Pearson and Kendall correlation of arthropod communities with the first 3 axes of NMS ordination for 2006 and 2007. 


\section{LIST OF TABLES}

Table

Page

11. Multi-Response Permutation Procedures (MRPP) for multivariate pairwise comparison of arthropod community composition between weed

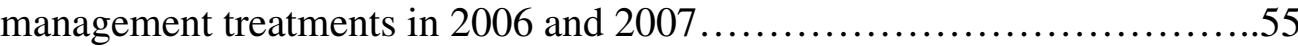

12. Percentage of predation shown by two carabid species on the seeds of eight weed species under laboratory conditions..............................56

13. Percentage of weed seed removed from seed cards by arthropods in a Zinfandel vineyard in Central Coast California, USA, in June and August, 2007........................................................57 


\section{LIST OF FIGURES}

Figure Page

1. Vegetation biomass in five weed management tactics in a vineyard in CA, USA, in 2006 and 2007. Error bar represent 95\% confidence intervals For mean weed biomass. ...............................................43

2. Weed biomass per plant of Anagallis arvensis, Conyza canadensis, Epilobium brachycarpum and Sonchus sp. for cover crop, cultivation and untreated control. Error bars represent $95 \%$ confidence intervals for mean weed biomass. .....................................................46

3. Nonmetric Multidimentional Scaling ordination showing distinct arthropod community compositions between herbicide and non-herbicide treatments including relationships to species richness $(R)$, evenness $(E)$ and diversity $(H)$ for arthropods (Arthr) and plants (Plant) in 2006 and 2007. Monte Carlo Test axis $2(P=0.058$ for $2006 ; P=0.048$ for 2007$)$ and axis $3(P=0.019$ for 2006; $P=0.048$ for 2007 


\section{Literature Reviews}

Weed is a term referring to plant that grows where humans do not want it to grow. There are a variety of reasons why weed is not desirable, with the most obvious one being a nuisance. For example, many people do not like weeds growing in their lawn, garden beds, or on the driveway. There are other less obvious reasons why we do not like weeds. Some people are allergic to weed pollen, which can causes asthma and nasal congestion, among other symptoms. Upon contact with bare skin some weeds such as Taxicodendron diversilobum (western poison oak) can cause severe allergic rashes and irritate susceptible person for weeks. Some exotic plants are classified as environmental weeds (i.e. Rubus discolor, Fallopia sachalinense, and Ulex europaeus), which invade wild areas and compete with native vegetations. Some weeds are toxic to livestock. For example, Euphorbia esula (leafy spurge) is a cosmopolitan species that can to lethal to cattle when ingested in large amount. With the later example in mind, weed in agricultural crop production is perhaps the most relevant to us humans because it affects our foods. Humans started to realize the detrimental effects of weeds, as mentioned in Diamond (1997), at the dawn of agriculture that started over 10,000 years ago: weed can compete with crop to an extend that affected the yield. Although the effects of weeds have been realized and control measures devised, the struggle between humans and weeds persisted to this day.

This paper deals with weeds in grape production, and grape is a big business in America. According to the United States Department of Agriculture, total grapevine acreage in California alone (including wine-type, table-type, and raisin-type grapes) was estimated at 
861,000 acres in 2006 (USDA, 2007). Controlling weeds in this industry is a great task and often accounts for the majority of expenses in crop production (Fischer et al., 2002). Weeds compete with grapevines for water and nutrients, thereby potentially reducing plant vigor and yield (Ingels et al., 2005; Hembree and Lanini, 2006). Studies have shown that full season competition due to unmanaged weeds could cause yield reductions by up to $37 \%$, cane weight by $68 \%$, number of cluster per vine by $28 \%$, and berry weight by $3 \%$ (Byrne and Howell, 1978). Thus, a $1.3 \mathrm{~m}$ wide strip under the vines (a.k.a. berm) is usually treated with different PRE herbicides during the dormant period of the vines although cover cropping, mowing, and disc cultivation are often used to manage vegetation in the aisles (i.e. area between vine rows) (Steinmaus et al. 2008).

This paper also deals with arthropods and their interaction with weeds in vineyards. Though weeds may interfere with grape production, they are key players in the agro-ecosystems. For instance, weed can add carbon to the soil and improve its structures, provide habitats and resources for many arthropods, and in some cases promote the abundance of natural enemies (Orr et al., 1997; Aguilar et al., 2003; Gerowitt et al., 2003; Marshall et al., 2003). Conversely, managing weeds can alter vegetation community and affect microenvironment variables in the ecosystem (Norris and Kogan, 2000), which in turn can change the arthropod community compositions and the functioning of ecological processes (Marshall et al., 2003). This later process in vineyard setting is not well understood. There are very few studies involving arthropod communities in vineyard, especially those that are classified as ground dwellers, and their roles as natural enemies of vineyard pests (Costello and Daane, 1998; Costello and Daane, 2003). 
Landis et al. (2000) stated that conservation biological control (of crop pests) involves manipulation of the environment to enhance the survival, fecundity, longevity, and behavior of natural enemies to increase their effectiveness. The goal of habitat management is, therefore, to create a suitable ecological infrastructure within the agricultural landscape to provide resources such as food for natural enemies, alternative prey or hosts, and shelter from adverse conditions. First step toward achieving this goal is to increase the availability of primary producers (plants), because they necessitate the nutrient cycling process in ecosystems and correlate to the functioning of many trophic levels (Norris and Kogan, 2000; Cardinale et al., 2006). Therefore, promoting weed can enhance ecological processes, but must be done so with caution because more vegetation in crop field does not always produce favorable arthropod communities, as shown by a comprehensive review of biodiversity in agriculture (Straub et al., 2007). The choice of weed management tool will plays a crucial role in structuring vineyard floor such that noxious weed population and crop economic injuries are minimized, but also promotes the conservation of natural enemies.

The following are documented benefits of weed management practices that promote biodiversity. A study conducted in a vineyard in California, found that the maintenance of floral diversity throughout the growing season increases the number of natural enemies, thereby reducing the numbers of western grape leafhoppers and western flower thrips (Nicholls et al., 2000). This result is likely to be associated with food availability and microclimate changes imposed by higher vegetation density (Zangger et al., 1994; Orr et al., 1997; Frampton et. al, 2000). A study in Hampshire, UK found that temperature in refuge 
habitat varies considerable less than bare ground, which consequently lead to an increased in terrestrial arthropod population density (Thomas et al., 1991). A weed management study in California vineyard found levels of phospholipid fatty acids (PLFA), an indicator of microbial total biomass present in the soil, to be significantly higher in cover cropped row middles compared to the machine-disked ones (Ingels et. al, 2005). Besides the positive impacts on diversity, factors such as soil physical properties also can improve in response to vegetation cover. For example, soil water infiltration rate was up to 50 times higher in a cover cropped vineyard compared to bare soil as a result of herbicide applications (Krohn and Ferree, 2005). Vegetations surrounding crop field can also influence biodiversity. For example, unsprayed landscapes surrounding farmland have been shown to play important roles in conserving and supporting populations of beneficial arthropods in the field (Thomas and Marshall, 1999). Thus, sustainable grape growing requires a systems approach which takes into account the effects of farming practices both within the vineyard and in the surrounding environment (Ingels 1992), and management goals where establishment and self-perpetuation of pest-prey interaction is ideal.

Ground beetles (Coleoptera: Carabidae) are widely recognized for their beneficial roles in agroecosystem (Kulman, 1974; Kromp, 1999; Coll and Guershon, 2002). Most carabids in temperate zone are ground dwellers, feeding on small invertebrate animals and seeds (Kulman, 1974). Widely studied genera of omnivorous carabids include Agonum spp., Amara spp., Harpalus spp., and Pterostichus spp (Chiverton and Sotherton, 1991; Kromp, 1999). Pterostichus melanarius (Illiger) is perhaps the most studied carabid in agriculture, especially for its role in insect biological control, that stemmed from a study which analyzed 
the gut content of adult females captured from barley field (Chiverton, 1984). Harpalus rufipes (DeGeer) and H. pensylvanicus (DeGeer) are also widely studied for their contribution to weed and insect pest suppression in field crops (Kulman, 1974). Seeds of the Poaceae, Brassicaceae, and Apiaceae are readily consumed by carabids belonging to the tribe Harpalini (Saska and Jarosik, 2001). Mixed diet consisting of seeds and mealworm given to Amara similata (Gyllenhal) has been shown to increase its larval survival and adult oviposition rate compared to prey only diet (Jorgensen and Toft, 1997). Information on carabids in agriculture is almost exclusively from studies in field crops (Kromp, 1999).

Several studies in annual farming systems have investigated the effects of habitat structure on arthropod communities and found higher numbers of predatory species to be present in weedy systems (Shelton and Edwards, 1983; Chiverton and Sotherton, 1991). Recent studies indicated that increasing groundcover diversity by planting cover crops could result in positive changes in soil resource availability, such as increases in organic matter and microbial biomass (Ingels et al., 2005), and this could be done without a concomitant increase in the abundance of weeds or a shift to weed communities that are more difficult to manage (Smith and Gross, 2007). Furthermore, increasing plant diversity augments the level of habitat structural complexity for herbivores (Marshall et al., 2003) providing resources to support higher predator density in agroecosystems (Andow, 1985), and potentially reducing the chance for crop pest outbreaks.

Few studies in perennial agricultural systems have investigated the effects of vegetation structural complexity on arthropod communities (Altieri and Schmidt, 1985; Wyss, 1996; 
Costello and Daane, 1998; O'Neal et al., 2005). Even fewer studies in perennial systems explicitly manipulated ground cover diversity and examined its arthropod assemblages (Costello and Daane, 2003). The effects of weed communities on terrestrial arthropod communities as a whole remain unclear, especially those of beneficial organisms and crop pests in vineyards, and whether the relationships between plant driven biological diversity and the ecosystem function reported in annual systems can be extrapolated to develop lowinput practices in vineyard agro-ecosystems. Therefore, there is a need for research to understand the interactions between biodiversity, ecosystem function and agricultural sustainability in such perennial systems (Marshall et. al, 2003). 


\section{Introduction}

The use of a pre- herbicide before bud-break in the spring raises questions about the need for controlling weeds when the vines are dormant and when most of the weeds present are winter annuals that will senesce before the vines reinitiate their growth. In addition, removing ground vegetation can have negative impacts such as increased risk of soil erosion and elimination of niches for other organisms. In order to develop more sustainable weed control practices in grapevine production, it is crucial to identify the most problematic weed species and the period during the growing season when they compete for water and nutrients (Baumgartner et al. 2008). Furthermore, the ability of grapevines to tolerate competition may depend on weed community, proximity of weeds to the vines, climate, soil conditions, and cultivar being grown (Monteiro and Lopes, 2007; Baumgartner et al., 2007). Regardless of the factors that affect grape production, many commercial vineyards routinely implement weed control methods such as herbicides, mono-species cover cropping, and cultivation in order to minimise the risk of economic damage (Hembree and Lanini 2006). Conventional strategies implemented in commercial vineyards on the Central Coast of California, USA, rely on the use of herbicides as the primary tool to manage weeds under the vines (e.g. vine row or berm) and the use of cover-crops, resident vegetation, or cultivation between vine rows (e.g. alley or middle). Mounting concern over the economic and ecological sustainability of conventional agricultural production has led to increased interest on alternative cropping systems that are less reliant on synthetic chemical inputs while thriving to maintain profitable crop yields (Buhler et al. 1992; Ingels 1992; Smith and Gross, 2007; Steinmaus et al., 2008). Besides the negative impact that weeds can have on vine growth, 
they can create a favourable environment for many organisms including natural enemies of pests (Orr et al., 1997; Aguilar et al., 2003; Marshall et al., 2003). Conversely, managing weeds can alter vegetation community and affect microenvironment variables in the ecosystem (Norris and Kogan, 2000), which can change the arthropod community composition and the functioning of ecological processes (Marshall et al., 2003). Is this bottom-up effect of weed on arthropod occuring in vineyards? Are more arthropods good for grape production? These questions remain to be answered, but it seems plausible that the ideal weed management practice is one that ameliorates noxious weeds while allowing benign vegetation to prosper, without jeopardizing crop productivity.

Strips of vegetation (or weed) through crop fields, or 'island' habitats, have been used as an alternative method of weed management that also enhances the abundance and activity of predatory arthropods in field crops (Zangger and Nentwig, 1994; Carmona and Landis, 1999; Kromp, 1999; Landis et al., 2000), and improved overwintering conditions for invertebrate predators in other annual systems (Thomas et al., 1991). Island habitats can be created for vineyards by maintaining resident-vegetation or a cover crop between vine (alleys middle or centers) rows, which many California Central Coast vineyards commonly practice.

However, this vegetation provides good coverage in the spring when the soil is moist, not during dry summer months, when only patches of hardy summer weeds are scattered randomly across the alleys. This phenomenon distinguishes the characteristics of vegetation strips in many California Central Coast vineyards from those planted in annual systems. The only way to maintain uniform vegetation strips in the vineyard alleys during the dry season is with irrigation, but this can easily double water usage in areas that already have high demand 
for water. Alternatively, uniform vegetation strips occur naturally in the vine row throughout the growing season as a direct result of the additional water from drip irrigation, in the event that herbicide use has been excluded.

In the present study, different weed control tactics were implemented to modify plant communities on vine rows (berms), and investigate their effects on grapevine performance, yield components, weed communities, and ground dwelling arthropod communities. The objectives of this research were to 1) evaluate the effectiveness of the different weed management practices, 2) identify weed community composition associated with each management practice, and 3) assess their impact on growth and yield components, 4) describe the relationship between weed control and vegetation and arthropod diversity, 5) identify carabid beetles that act as weed seed predators, and 6) evaluate the importance of vegetation composition and density on arthropod mediated weed seed predation. 


\section{Materials and Methods}

The study was conducted in a commercial wine grape vineyard in Paso Robles, California, USA during the 2006 and 2007 growing seasons (Elevation: $295 \mathrm{~m}$. Location: $35^{\circ} 33^{\prime} 42^{\prime} \mathrm{N}$ $\left.120^{\circ} 35^{\prime 2} 1^{\prime \prime} \mathrm{W}\right)$. The vineyard was planted in 1997 with Vitis vinifera L. 'Zinfandel' (clone $\mathrm{P} 1)$ on $110 \mathrm{R}$ rootstock, at a spacing of $2.13 \mathrm{~m}$ between vines and $2.44 \mathrm{~m}$ between rows for a planting density of 1923 vines per hectare. The vines were trained to a vertical shoot position, with rows on north-south orientation. The vineyard was drip irrigated, with sprinklers available for frost protection and cover-crop irrigation. Drip irrigation and fertilization were applied uniformly across all treatments, based on conventional practices for commercial production. The native vegetation of the area is savannah, consisting mainly of grasses and oak trees. The summers are dry, and the highest temperature may reach up to $46.1^{\circ} \mathrm{C}$. Mean annual temperature ranges from $12.8^{\circ}$ to $15.6^{\circ} \mathrm{C}$ and the precipitation from 305 to $457 \mathrm{~mm}$. The freeze-free period is about 225 to 250 days (National Weather Service, 2007). The soil type is Arbuckle-San Ysidro complex, 2 to $9 \%$ slopes with a sandy loam texture.

The experiment was arranged as a randomized complete block design, with five treatments and three replications in 2006 adding a fourth one in 2007. Each experimental unit consisted of four vine rows, $170 \mathrm{~m}$ long with two additional adjacent buffer vine rows. The weed control treatments were placed in the $1.3 \mathrm{~m}$ wide section right under the vine rows (berm).

The five treatments were 1) flumioxazin (Chateau, $510 \mathrm{~g}$ a.i. $\mathrm{kg}^{-1}, \mathrm{SW}$, Valent) at $428 \mathrm{~g}$ a.i. $\mathrm{ha}^{-1}, 2$ ) simazine (Princep 4L, $480 \mathrm{~g}$ a.i. $\mathrm{L}^{-1}, \mathrm{~S}$, Syngenta) at $5.3 \mathrm{~kg}$ a.i. ha ${ }^{-1}, 3$ ) cultivation, 4) 
cover crop, and 5) untreated control. In the $1.14 \mathrm{~m}$ wide vineyard middles (aisles), a cover crop mainly comprised of Bromus carinatus Hook and Arn. was planted and maintained by mowing it each year during the spring.

The simazine and flumioxazin treatments were applied with a commercial sprayer in February, each as a tank mix with oxyfluorfen (Goal 2XL, 240 g a.i. $\mathrm{L}^{-1}$, S, Dow Agrosciences) at $680 \mathrm{~g}$ a.i. $\mathrm{ha}^{-1}$ and glyphosate (Roundup Original Max, $540 \mathrm{~g}$ a.e. $\mathrm{L}^{-1}, \mathrm{~S}$, Monsanto) at $700 \mathrm{~g}$ a.e. $\mathrm{ha}^{-1}$ as growers in the region commonly do. Cultivation was conducted once a year in late spring when weeds covered about $75 \%$ of the ground and were about $30 \mathrm{~cm}$ tall. Cultivation was done with a Pellenc Tournesol 2250 AR, which consisted of a shroud assembly mounted on automatic articulating arms positioned perpendicular to the direction of the movement on each side of the tractor. There were two metal blades in each of the $0.5 \mathrm{~m}$ diameter shrouds that could penetrate the soil up to $8 \mathrm{~cm}$ deep. When inserted below the soil surface, the blades severed weed shoots from their roots. The cover crop was comprised of ten, low growing species (Table 1), which were sown by hand at approximately $22 \mathrm{~kg} \mathrm{ha}^{-1}$ prior to a significant rain event in February of each year. The control plots were left untreated during the growing season. Weed control under the vines of buffer rows between blocks was done using a tank mix of oxyfluorfen, glyphosate and simazine in February as mentioned before. Paraquat (Gramoxone Inteon, $240 \mathrm{~g}$ a.i. $\mathrm{L}^{-1}$, S, Syngenta) was applied at $1.1 \mathrm{~kg}$ a.i. $\mathrm{ha}^{-1}$ to all the treatments and buffer rows, with exception to the cover crop treatment, after harvest in November. This latter herbicide application was done to kill the weeds that escaped the treatments over the growing season. 
Grapevine performance and yield components

Canopy and yield components were measured in four vines that were randomly selected within each experimental unit. Grapevine leaf area was indirectly measured using a $1 \mathrm{~m}$ long PAR-light sensor ${ }^{2}$ to evaluate light interception percentage (LI). LI samples were taken between June and October. The light sensor was held horizontally below the lowermost leaf in the vine canopy (De Cortazar et al. 2005), and positioned between the second and the third node of the larger of the two main branches, always perpendicularly to the vine row facing east. The measurements were done between 12 p.m. -1 p.m. (solar zenith). Number of grape clusters, berry count per cluster, berry weight, and fruit weight per vine were determined when all the experimental units reached the minimum harvest criterion (i.e. at least $20^{\circ}$ brix). Number of berries per cluster and berry weight was evaluated from two randomly selected fruit clusters at each vine. After harvest, the grapes from each experimental unit were combined and crushed, then a $50 \mathrm{ml}$ sample of fresh grape juice was analyzed for brix degrees, titratable acidity, and $\mathrm{pH}$ using a near infrared scanning spectrophotometer ${ }^{3}$. Grapevine size was measured by cane weight after leaf-drop (Byrne and Howell 1978). All the shoots were pruned to two bud spurs.

\section{Plant diversity data collection}

Berm vegetation density of each species present was assessed monthly from March until November in four randomly assigned points within each experimental unit using $0.25 \mathrm{~m}^{2}$ frames. Two samples of above-ground vegetation biomass per experimental unit were taken 
concurrently with the sampling of vegetation density in April, June, July, and October. Shoots from each species were harvested by cutting plants at the soil surface level. Dry matter per species was determined. Plant species from the survey were grouped in functional groups (i.e. annual grass, annual broad-leaved, perennial grass and perennial broad-leaved species) (Monteiro and Lopes 2007). Individual biomass of Anagallis arvensis, Conyza canadensis, Epilobium brachycarpum, and Sonchus sp. were calculated by dividing biomass by density.

\section{Arthropod diversity data collection}

Flightless, ground dwelling arthropod activity-density was sampled each month between February and October using pitfall traps. Each trap consisted of a $9 \mathrm{~cm}$ wide and $7 \mathrm{~cm}$ deep round plastic cup. The traps were buried into the ground with the top rim level with the soil surface. Three pitfall traps were placed in the central vine row of each experimental unit. The traps were located at least $25 \mathrm{~m}$ away from the edge of the plot, and were spaced $10 \mathrm{~m}$ from each other in a transect. Each trap was filled half-full with $10 \%$ ethylene-glycol solution. Detergent was added to reduce water tension and minimize arthropod escapes (Purtauf et al., 2005). Traps were set for 48 hours each month, and closed between evaluations. All arthropods found in the pitfall traps were recorded except for flies (Diptera) and flying wasps (Hymenoptera). Only one spider species, Trachelas pacificus Chamberlin and Ivie, was recorded because it was found frequently in most pitfall traps. Most of the remaining arthropods were identified to genus, and if possible, to species by specimen comparison at the Bohart Museum of Entomology, Davis, California. Some of the species 
that accounted for less than $5 \%$ of the arthropods captured in the pitfall traps were identified only to the family level.

Seed predation studies

Laboratory experiments were conducted in 2006 to assess the potential of Tanystoma maculicolle Dej. and Calathus ruficollis Dej. (Coleoptera: Carabidae) to feed on seeds of Amaranthus retroflexus, Anagallis arvensis , Brassica nigra, Capsella bursa-pastoris, Eragrostis spp., Malva parviflora, Picris echioides, and Sonchus oleraceous. These plant species were chosen due to their prevalence in California Central Coast vineyards, and their wide range of seed shapes and sizes. The beetle species were chosen because they were the most active ground beetles assessed using pitfall trapping (Greenslade, 1964; Carmona and Landis, 1999; Kromp, 1999). The seeds and the beetles were collected in the experimental field. After collection, the beetles were acclimated to laboratory conditions, and fed with dry cat food until 48 hours prior to the initiation of the experiment period during which the beetles were starved. An unsexed beetle was placed in a $10 \mathrm{~cm}$ Petri dish that contained 30 seeds of a weed species, and a wet cotton ball for humidity. There were six replications for each beetle and weed species combination. The experiment was conducted for 48 hours, in a growth chamber at $21^{\circ} \mathrm{C}$, and it was repeated once. The photoperiod was 14 hours of light and 10 hours of darkness. At the end of the experiment, the number of intact seeds was determined. 
Invertebrate weed seed predation in the field was measured in May and August of 2007 to represent early and mid- growing season, and when the activity of arthropods was high and the seeds of weed species tested had been dispersed and can be normally found on the ground. The two treatments were a vertebrate exclusion cage and a no cage control. Thirty seeds of each weed species were combined and placed on a $14 \mathrm{~cm}^{2}$ seed card $\left(1530\right.$ seeds $\mathrm{m}^{-}$

${ }^{2}$ ). The seeds were secured onto the cards using glue. The cards were flushed and pinned to the soil surface on the berm. For vertebrate exclusion treatment, the card was enclosed within a wire cage $\left(15 \mathrm{~cm} \times 15 \mathrm{~cm} \times 15 \mathrm{~cm}\right.$, mesh size $\left.=1.25 \mathrm{~cm}^{2}\right)$, which permitted access to the seed to invertebrate but not to vertebrate seed predators (Menalled et al., 2000). Cards with no cages were used for the controls. Each experimental unit had three caged cards and three no-cage cards that were randomly placed on the berms. Seeds from two weed species, Brassica nigra and Capsella bursa-pastoris, were used as seed predation indicators based on the preference by $C$. ruficollis and $T$. maculicolle observed in the laboratory experiment. The experiment was conducted for 48 hours, after which the number of intact seeds was recorded. Invertebrate seed predators were assumed to be responsible for the missing or damaged seeds on the caged seed cards.

\section{Data analysis}

Univariate data analyses were done using Minitab ${ }^{4}$. ANOVA was conducted, following transformation of data to $\log _{10}(n+1)$ if necessary to stabilize the variance, with treatments as main effect and block as random factor, to determine the effects of different weed management practices on vegetation and arthropod communities. Repeated measure 
ANOVA (Ingels et al. 2005) was used to determine how treatment and time influenced weed biomass, where between-subject factors included treatment type and block and within-subject factors was time. Vine light interception, yield components, and cane weight were analyzed using ANOVA, with treatments as main effect and blocks as random factor. Tukey's Studentized Range (HDS) method was used for treatments mean separation $(\alpha=0.05)$.

Regression analyses were performed to determine relationships between plant and arthropod variables in each weed management practice using values obtained from averaging the sampling dates for each experimental unit. Species richness, evenness, and Shannon-Weiner Diversity Indexes (Sosnoskie et al., 2006) of vegetation and arthropods were evaluated and then analyzed using ANOVA. Prior to computation of diversity indexes and statistical analysis, the data of plant density and arthropod activity-density from different sampling dates were averaged per experimental unit. Plant and arthropod species richness was obtained from total count of species present in each experimental unit for both arthropod and plant data. Additional ANOVAs were conducted on the activity density of T. maculicolle and C. ruficollis. Tukey's Studentized Range (HDS) method was used for treatments mean separation $(\alpha=0.05)$.

The proportion of seeds lost due to invertebrate removal was calculated for each laboratory and field experiment by comparing the total number of seeds offered and the total recovered. The data for each weed species were analyzed separately using paired $t$-test for the laboratory experiment, and ANOVA for the field experiment. 
Multi-Response Permutation Procedure (MRPP; PC-ORD 5.11 ${ }^{5}$ ) was used to test for significant differences in arthropod communities (based on the activity-density of each species) between treatments. This technique is similar to MANOVA and related methods; however MRPP provides a nonparametric analysis and does not require the assumptions of multivariate normality, linearity, and homogeneity of variance (McCune et al., 2002). Sorensen distance metrics were used to determine the similarity of sample units (15 in 2006 and 20 in 2007) based on the $\log _{10}(n+1)$ transformed density of each species from each plot. The effects of management system (treatment) on arthropod community composition were further analyzed using Nonmetric Multidimensional Scaling (NMS) ordination with Sorensen distance as the similarity measure. NMS was used to compare arthropod samples from each plot $(\mathrm{n}=\mathrm{x}$ plots $)$ and to show how habitat or treatment variables are related to community composition. Because rare species can affect NMS results (McCune et al., 2002), species found in less than $5 \%$ of the sample units were considered rare, and were therefore removed prior to the analysis. "Autopilot mode" in PC-ORD 5.11 (McCune and Mefford, 1999) was used to determine the best six axes solution to each iteration. Four hundred iterations were performed on randomized data, as described by Menalled et al. (2007), to determine the statistical significance of each ordination axis. Biplots were created using the two ordination axes that represented the most variation in the original species data. The proportion of variance represented by each of the final dimensions was evaluated based on the correlation coefficient $\left(\mathrm{r}^{2}\right)$ between Sorensen distance in ordination space and original space. Linear relationships between community composition and treatment/environmental variables were examined by correlations between these variables and ordination axes. 


\section{Results}

\section{Treatment Efficacy}

Total weed density and biomass varied among treatments and years. In 2006, rainfall was above the average for the California Central Coast $(364 \mathrm{~mm})$, and in 2007 the precipitation only amounted to $31 \%$ (104 $\mathrm{mm}$ ) of the previous year. Inconsistent weather patterns between the two years of the study likely influenced the results. Flumioxazin was the most effective treatment in reducing weed biomass in 2006, and equally effective as simazine in 2007 (Figure 1). Flumioxazin and simazine were evidently more effective than the other treatments in reducing weed density and biomass (Table 2 and 3). In 2006, one pass of cultivation in late April, when vegetation biomass was about $50 \mathrm{~g} \mathrm{~m}^{-2}$, reduced this vegetation by $54 \%$, which was equivalent to the biomass shown by flumioxazin and simazine almost until July (Figure 1). Furthermore, biomass sampled at the end of the 2006 season showed no difference between cultivation and simazine, and both were slightly higher than flumioxazin (Figure 1). The efficacy of the cultivation treatment was notably reduced by the hard, dry soil conditions in 2007, where it was difficult for the cultivator blades to penetrate the soil and sever weed roots from their shoots. Consequently, the escaped weeds were able to proliferate in the cultivation treatment with the supply of moisture from drip irrigation, which resulted in 17\% higher weed biomass in 2007 compared to 2006 (Table 3). In 2006, the cover crop and untreated control had about the same amount of plant biomass (Table 3), and collectively both treatments had about ten times higher plant biomass than flumioxazin, and up to twice as much as cultivation (Table 3). Furthermore, in the cover crop, plant 
biomass was higher than the untreated control in the second year, regardless of dry conditions. In 2007, the cover crop treatment showed 0.3, 3, and 39 times higher plant biomass compared to the untreated control, cultivation, and herbicide treatments, respectively (Table 3). This was likely due to the advantage in rapid growth of having established perennial species. Finally, in 2007, the untreated control had 2.4 and 29 times higher plant biomass proportionally compared to the cultivation and herbicide treatments, respectively (Table 3).

There were differences in weed control effectiveness at the species level that were not evident when considering weed biomass of the community as a whole. For instance, weed density in cultivation and untreated control were not different in 2006, but weeds in the untreated control had almost three times higher biomass per individual (Figure 2). Likewise, weed biomass in the cover crop and untreated control were not different in 2006, but cover crop yielded 39\% less biomass per individual weed plant (not the cover crop species planted) compared to the untreated control.

\section{Weed composition}

Flumioxazin and simazine were predominantly dominated by annual grass and followed by annual broadleaf species. Cultivation and untreated control were dominated by annual broadleaf species, and cover crop was dominated by perennial grass and perennial broadleaf species (Table 2 and 3). 
Impacts on vine growth and yield components

There were treatment effects on grapevine canopy light interception (LI) during both years of the study. LI was lowest in the untreated control, highest in the herbicide treatments, and intermediate in cultivation (Table 4). Therefore, the herbicide treatments had denser canopies and a higher leaf area than the rest of the treatments. Clearly, a denser canopy favored vine growth and yield (Table 5). For instance, although there was variation among years, the highest cane weight was observed in the herbicide treatments, and lowest in the untreated control. There were clear differences in production among treatments and years. In 2006, flumioxazin, simazine, and cultivation yielded around $22.4 \mathrm{~kg}$ vine ${ }^{-1}$, cover crop $18.9 \mathrm{~kg}$ $v^{2} e^{-1}$, and the untreated control $16.4 \mathrm{~kg}$ vine $^{-1}$. In 2007, flumioxazin and simazine yielded on average $15.4 \mathrm{~kg}$ vine $\mathrm{e}^{-1}$, cultivation about $12 \mathrm{~kg} \mathrm{vine}^{-1}$, the cover crop and the untreated control yielded approximately $8.25 \mathrm{~kg}$ vine $^{-1}$.

Yield components were lower in all treatments in 2007 compared with the previous year (Table 5). For instance, yield in the herbicide treatments were collectively $31 \%$ lower in 2007 compared to 2006 (Table 5). In 2007, yield in cultivation was $22 \%$ lower than the herbicide treatments, and was $50 \%$ that of the previous year. The cover crop treatment did not have lower yield than the untreated control, despite having $34 \%$ higher total plant biomass on the berm in 2007 (Table 3 and 5).

The differences observed in yield components were due not only to fewer fruits, but also smaller clusters and berries in the cover crop and untreated control (Table 5). In 2007, the 
number of cluster was highest in the herbicide treatments, and berry weight was lowest in the untreated control and cover crop (Table 5). Brix degrees were the only juice parameter slightly affected by management practices, and was found to be $10 \%$ lower in 2006 in the cultivation compared to the rest of the treatments (Table 6). The overall effect of weed competition was on fruit size and not the juice quality parameters tested in this study.

\section{Plant Density and Diversity}

Plant density was highest in the cover crop followed by the control and cultivation treatments (Table 2). The herbicide treatments had the lowest plant densities being $26 \%$ in 2006 and $2 \%$ in 2007 compared to the other treatments. The number of plant species within the vineyard ranged from 15 to 31 in the 2006, and 6 to 26 in the 2007 (Table 7). Collectively, the mean number of plant species found in the herbicide treatments was $60 \%$ that of the untreated control and cover crop in 2006, and 29\% in 2007 (Table 7). Additionally, plant community evenness was up to four times higher in the non-herbicide treatments compared to the herbicide treatments for both years (Table 7).

Plant diversity was highest in the cover crop and untreated control, intermediate in the cultivation, and lowest in the herbicide treatments regardless of years (Table 2). In general, the cover crop and untreated control had up to sixteen times higher plant diversity compared to flumioxazin and simazine (Table 2). Under cultivation, plant diversity was about $10 \%$ lower compared to the cover crop and untreated control, and about thirteen times higher than the herbicide treatments. 


\section{Arthropod Diversity}

Fifty-seven arthropod species were captured and identified to genus and as possible to species (Appendix 1). The highest numbers of individuals captured were in the families Entomobryidae (Collembola), Formicidae, Carabidae, Corinnidae (Araneae), Anthicidae, and Tenebrionidae, respectively. The number of arthropod species encountered was always higher in the non-herbicide treatments, especially in the cover crop and untreated control, where on average 10 more species were captured than the herbicide treatments in the 2006 , and 6 more species in the 2007 (Table 3). The cultivation had more arthropod species than the Flumioxazin and Simazine only in 2007. Considering the magnitude of the difference in plant diversity between treatments (Table 8), the difference in arthropod diversity was small, but there was a tendency to be higher in the non-herbicide treatments and particularly in the cover crop (Table 8). Species evenness was the only arthropod community parameter unaffected by either treatment or year.

Marked differences in arthropod activity density were found only in 2007 (the dry year), when up to twice as many arthropods were captured in the cultivation and untreated control compared to the herbicide treatments (Table 8). There were differences in arthropod abundance at the species level that were not evident when considering the total number of individuals of the community as a whole. For instance the number of $C$. ruficollis individuals captured was highest in the cover crop, which was up to four times more than in the herbicide treatments (Table 3). On the other hand, Tanystoma maculicolle was a very 
mobile beetle based on laboratory observations, and the number of individuals captured in the field varied between treatments and years without showing a clear trend (Table 8).

\section{Plant and arthropod diversity relationship}

Regression analyses revealed an overall positive relationship between plant density and diversity and arthropod diversity (Table 9).

The NMS ordination was performed in order to extract the patterns of arthropod community composition in each weed management system. For 2006, the first ordination axis represented $39 \%$, the second axis represented $27 \%$, and the third $14 \%$ of data variation. For 2007, the first, second and third ordination axes represented 15, 23 and 55\% of the variation in the data, respectively. For 2006, the third axis strongly correlated to plant species richness $(\mathrm{r}=0.86)$ and diversity $(\mathrm{r}=0.79)$. For 2007 , the second NMS axis was strongly correlated to arthropod diversity $(r=-0.82)$ and evenness $(r=-0.76)$, and the third NMS axis was strongly correlated to plant density $(r=-0.81)$, species richness $(r=-0.81)$, and diversity $(r=-0.74)$ (Table 10) although treatment group separation was not apparent. Biplots were created using the second and third axes, which mutually represented $41 \%$ in 2006 and $77 \%$ in 2007 of the arthropod community structure variation. Both the 2006 and 2007 diagrams revealed significant differences in arthropod composition between herbicide and non-herbicide treatments $(P<0.001)$, with sample units of cultivation lying between these groups (Fig. 3). 
Further analyses were conducted to determine the arthropod species most responsible for variations observed in the ordination axes. We found that dominating species of predators and decomposers such as Armadillidium vulgare $\left(\mathrm{r}^{2}=0.82\right)$, Forficula aricularia $\left(\mathrm{r}^{2}=0.52\right)$, Solenopsis xyloni $\left(\mathrm{r}^{2}=0.82\right)$, and Trachelas pacificus $\left(\mathrm{r}^{2}=0.59\right)$, were highly correlated with the biplot axes. Finally, multivariate pairwise comparison using MRPP (Table 11) confirmed the difference in arthropod communities observed on the NMS biplots (Fig. 3). In both years, arthropod community composition was similar in the flumioxazin and simazine treatments, the cultivation treatment showed similarities with the other treatments, followed by the untreated control that differed from the herbicide treatments. Interestingly, the arthropod community composition of the cover crop was different from the untreated control $(P \leq 0.03)$.

\section{Arthropod Seed Predation}

The laboratory seed predation experiments on eight weed species revealed that only $B$. nigra and C. bursa-pastoris were readily consumed by the two carabid species (Table 12). Calathus ruficollis preferred C. bursa-pastoris over B. nigra, while T. maculicolle showed no preference between these two weed species.

In 2007, an exclusion predation study under field conditions using B. nigra and C. bursapastoris seeds was conducted to determine if a higher density of seed predators in the nonherbicide treatments would translate into higher seed predation. The results showed no differences in seed removal between exclusion treatments (data not shown). Therefore, the 
majority of seeds removed were attributed to invertebrates, and thus data from both treatments are presented combined. The highest values of weed seed removal were found in the cover crop and untreated control, particularly in August when the removal of B. nigra was up to twice the values observed in Flumioxazin and Simazine treatments (Table 13). Seed removal in the cultivation was generally higher than in the herbicide treatments, but the difference was significant only for the seeds of $C$. bursa-pastoris in August (Table 13). 


\section{Discussion}

The effects of various weed management practices on weed abundance, grapevine growth, and yield components varied among years. The high rainfall experienced in 2006 could have promoted simazine runoff reducing the effectiveness of this treatment (Troiano and Garretson 1998). The difference in yield between the two years in the non-herbicide treatments are likely due to the low rainfall registered in the region in 2007 , which affected the level of competition tolerable by grapevines (Monteiro and Lopes 2007). Unmanaged weeds in a low rainfall year caused up to $48 \%$ reduction in yield (Table 5). It is likely that the observed yield reductions were a result of the different groundcovers causing water stress (Krohn and Ferree 2005) and nutrient competition (Ingels et al. 2005). Yield was the same in cover crop and untreated treatments despite 34\% higher groundcover biomass in the former, suggesting that certain weed species were more competitive than the cover crop species planted. Therefore, it seems that the level of weed-vine competition may be determined by community structure and perhaps driven by population size of problematic species present (Figure 1). Smaller berries resulted from weed competition and water stress, however, have a higher skin-juice ratio, which could potentially increase wine quality (Monteiro and Lopes 2007; Wade et al. 2004).

The weed management treatments generated clear differences in plant community parameters such as richness, density and diversity. Thus, control practices can importantly modified weed communities in perennial cropping systems (Aguilar et al. 2003; Baumgartner et al. 2007; Monteiro and Lopes 2007). The introduction and promotion of perennial species in the 
cover crop might not be only beneficial for it provides extended soil protection period (Aguilar et al. 2003), but also it might explain differences among treatments in individual biomass of several annual weed species. For example, Anagallis arvensis, Conyza canadensis, Epilobium brachycarpum, and Sonchus sp. had significantly lower individual biomass in the cover crop compared to the untreated control (Figure 2). These results support the idea that the proliferation of certain weed species in orchard ecosystem could be contained by artificially increasing plant species richness (Chen et al. 2004).

It was predicted that the herbicide treatments would show lower diversity and densities than the rest of the treatments, and that the cover crop should have the highest values. However, the cover crop, which introduced ten plant species to the system, had the same richness than the control. Thus, it seems that increasing plant species richness changed the structure of the native weed community by suppressing several species (Leps et al., 2001). Drought is believed to be partially responsible for the notable decline in plant species richness and density in 2007, year in which rainfall represented $29 \%$ of the previous year. Present study showed that the plant densities and biomass observed in the cultivation, cover crop and control treatments reduced 0,13 , and 24\% in 2006 and 22, 45 and $48 \%$ in 2007 respectively compared to the herbicide treatments. For this reason, it is concluded that vines can tolerate certain levels of vegetation on the berm when properly timed post-emergence control actions are taken. However, during dry years, the vine competition capacity could be compromised, and more intense approaches such as the use of pre-emergent herbicides would be justified to maintain yields. 
These results indicate that vegetation ground coverage and species composition might be important driving factors in the plant and arthropod diversity relationship. Furthermore, arthropod species such as $C$. ruficollis were markedly more active in the cover cropped areas, suggesting that this vegetation may favour particular organisms compared to the weedy systems (i.e. cultivation and untreated control).

In annual cropping systems, higher arthropod activity-density has been observed in areas covered with vegetation than areas without it (Lys and Nentwig, 1992; Carmona and Landis, 1999; Hummel et al., 2002). In the present study, arthropod community differences were not as evident as the ones observed for plant communities. Pitfall trapping was more useful to identify differences in species richness and diversity than abundance. It is possible that in the non-herbicide treatments the conditions favored more arthropod species and perhaps individuals, but the microhabitat generated reduced the need for these individuals to move seeking for food, moisture, oviposition sites, or refuge (Thomas et al., 2006). Also, it has been suggested that pitfall trap catching is negatively affected by the amount of vegetation immediately surrounding the trap (Greenslade, 1964; Thomas et al., 2006). Thus, dense vegetation in the non-herbicide treatments could have acted as a physical barrier to arthropod movement and led to the underestimation of their communities in these treatments. Therefore, the beneficial effect of ground vegetation on arthropod communities could be higher than what our results showed.

The magnitude of arthropod activity density response to vegetation communities varied among species and years (Table 8). Similarly to the effect on plant communities, this 
variation may be attributable to the differences in rainfall between years. Drought has been found to negatively affect the abundance of arthropods on farmland through changes in vegetation structural complexity and decreased water content near the soil surface (Frampton and Dorne, 2007). Hence, we believe that the greatest difference in arthropod activities between the herbicide and non-herbicide treatments was more pronounced in the drier year (e.g. 2007), due in part to the greater groundcover reduction in herbicide treatments (Table 2).

Arthropod abundance and diversity was proportionally related to the amount of vegetation cover and diversity parameters similarly to what has been reported for field margins where herbicides were excluded (Thomas and Marshall, 1999). Generally, plant diversity is considered one of the major ecosystem components favoring arthropod diversity (Norris and Kogan, 2000). It is important to mention that due to the strong relationship between plant diversity and density observed in the present study, it is not possible to clearly determine which parameter was more important to promote arthropod diversity. However, the cover crop had similar plant diversity, but higher plant density than the untreated control, and the former had higher arthropod diversity than the latter (Table 7 and 8). Additionally, the arthropod community assemblage differed between these two treatments (Fig. 3). Therefore, it seems that plant density could have played a major role in determining arthropod diversity. It can be proposed that this result could also be attributed to plant biomass, but this is unlikely because the cover crop and the untreated control had the same plant biomass in 2006 (Table 3). Furthermore, despite having similar plant diversity indexes, the cover crop and the 
untreated control treatments were comprised of different plant species, so plant community structure also could have influenced arthropod community assemblage and diversity.

Overall, the results of this study were consistent with previous findings in perennial systems, which indicated that weed management practices affect groundcover vegetation (Monteiro and Lopes, 2007) and can influence the composition of terrestrial arthropod communities (Altieri and Schmidt, 1985; Costello and Daane, 1998; O’Neal et al., 2005). Thus, incorporating vegetation strips as a part of weed management practices in vineyards, whether using resident vegetation or low-growing cover crop species, can help neutralized the impacts of herbicides on biodiversity of the system.

It has been proposed that the augmentation of biological diversity in agroecosystems can foster more active biological functions such as nutrient cycling and pest control (Altieri, 1999). It is likely that there were more seed predators in the non-herbicide than in the herbicide treatments (Menalled et al., 2001). Two aspects justify this assertion: 1) higher number of B. nigra and C. bursa-pastoris seeds were removed in the non-herbicide treatments under field conditions, and 2) the arthropod community assemblages of these treatments were highly determined by predator and decomposer species. Studies have found that more than 40 insect families belonging to 12 orders include at least one omnivorous species (Coll and Guershon, 2002). The two carabid species, T. maculicolle and C. ruficollis, included in the laboratory experiments, were thought to be mainly carnivorous (Lindroth, 1974). Our laboratory observations revealed that although these species would indeed consume insect carcasses when given the opportunity (data not shown), these beetles also 
readily consume considerable amounts of $B$. nigra and $C$. bursa-pastoris seeds, in the absence of insect prey. Therefore, we consider that these two carabids are omnivores and that they could behave as weed seed predators in agricultural fields and may have contributed to field seed predation results.

Concerns remain over the detrimental effects that weed competition poses on crop productivity Table 4 and 5. Therefore, it is crucial to understand the effects of weed-vine competition in order to make a justified weed management decision that not only maintains profitability but also promotes biodiversity. For instance, one could interplant a diverse mix of drought tolerant cover crops in the middles, and use alternative weed management practices such as cultivation on the berm, in order to dampen possible detrimental effects on grapevine growth while preserving habitat structural complexity. Another possibility is to plant cover crops during the winter-spring period and then cut them and use them as mulches on the berm, strategy that has proven to be cost-effective (Steinmaus et al., 2008). Furthermore, as previous studies have suggested, planting key species such as Dactylis glomerata L., Holcus lanatus L., and Lolium perenne L. can improve conditions for beneficial insects (Thomas et al., 1991; Orr et al., 1997). 


\section{Conclusions}

Effective weed and pest control strategies in cropping systems must provide permanent habitats that act as reservoirs for cyclic colonization of natural enemies (Wissinger, 1997). Therefore, we propose using vegetation strips in vineyards to preserve and enhance beneficial arthropod communities, and increasing plant density and diversity seems to be an effective way to achieve this goal. The role of certain weed species in supporting biological diversity within crop fields has been demonstrated for an extensive number of phytophagous insects, which consume weed species as food source (Marshall et al., 2003). This study demonstrated that weed control tactics that properly manage floor vegetation without eliminating it completely could be used to balance ecological interactions between the crop, weeds, insect pests and beneficial insects, by creating more favorable habitats within the vineyard. 


\section{Management Implications}

There are various weed management methods that could be used as alternatives to herbicide, which when applied at the right time, provide sufficient control of problematic species while sustaining a healthy crop (Aguilar et al. 2003). Our results were consistent with previous findings in Merlot vineyards that indicated that up to $100 \mathrm{~g} \mathrm{~m}^{-2}$ of aboveground biomass at the end of the growing season might have limited impacts on yield (Baumgartner et al. 2007). The present study showed that yield in the cultivation was affected by weed competition when seasonal average aboveground biomass reached as high as $105 \mathrm{~g} \mathrm{~m}^{-2}$ in 2007 (Table 3). Furthermore, our results indicated that the critical period of weed competition for Zinfandel grape occurs during budbreak-bloom period. This was determined because the absence of weed control during the first half of the growing season did not cause dramatic yield reductions although this will depend on environmental conditions, especially soil moisture. It seems plausible for a vigorous vineyard to reduce production costs by not controlling weeds during one year without importantly affecting yields. Conversely, if the vineyard is not vigorous and water is limiting, the use of PRE herbicides could prove important to maintain vine yield and vigor. Another alternative is to plant cover crops during the winterspring period and then cut them and use them as mulches on the berm, strategy that has proven to be cost-effective (Steinmaus et al. 2008). Our results indicated that vines can tolerate a certain amount of weeds in the berm, and that properly timing one pass postemergence control tactics (e.g. cultivation or POST herbicides) could provide the necessary level of control to obtain the desired yields. 


\section{BIBLIOGRAPHY}

Aguilar, V., Staver, C., and Milberg, P. 2003. Weed vegetation response to chemical and manual selective ground cover management in a shaded coffee plantation. Weed Research 43, 68-75.

Altieri, M.A. and Schmidt, L.L. 1985. Cover crop manipulation in Northern California orchards and vineyards: effects on arthropods communities. Bio. Agric. Hort. 3, 1-24.

Altieri, M.A. 1999. The ecological role of biodiversity in agroecosystems. Agric. Ecosyst. Environ. 74, 19-31.

Andow, D.A. 1985. Plant diversification and insect populations in agroecosystems. In: Some aspects of pest management (eds. Pimentel, D., Ingels, R., McGourty, G. and Christensen, P.). pp. 277-248. Cornell University Press, Ithaca, NY, USA.

Baumgartner, K., Steenwerth, and Veilleux, L. 2007. Effects of organic and conventional practices on weed control in a perennial cropping system. Weed Science. 55, 352-358.

Baumgartner, K., Steenwerth, K., and Veilleux, L. 2008. Cover-crop systems affect weed communities in a California vineyard. Weed Science 56, 596-605.

Buhler, D. D., Gunsolus, J. L., and Ralston, D. F. 1992. Integrated weed management techniques to reduce herbicide inputs in soybean. Agron. J. 84, 973-978.

Byrne, M.E. and Howell, G.S. (1978) Initial response of Baco noir grapevine to pruning severity, sucker removal, and weed control. Am. J. Enol. Viti. 29, 192-198.

California Department of Pesticide Regulation (CDPR). 2007. Annual pesticide use report. http://www.cdpr.ca.gov/docs/pur/purmain.htm 
Cardinale, B.J., D.S. Srivastava, J.E. Duffy, J.P. Wright, A.L. Downing, M. Sankaran, and C. Jouseau. 2006. Effects of biodiversity on the functioning of trophic groups and ecosystems. Nature Publishing Group. 443, 989-992.

Carmona, D.M. and Landis, D.A. 1999. Influence of refuge habitats and cover crops on seasonal activity-density of ground beetles (Coleoptera: Carabidae) in field crops. Environ. Entomo. 28, 1145-1153.

Chen, X., Tang, J., Fang, Z., and Shimizu, K. 2004. Effects of weed communities with various species numbers on soil features in a subtropical orchard ecosystem. Agric. Ecosyst. Environ. 102, 377-388.

Chiverton, P.A. 1984. Pitfall-trap catches of the carabid beetle Pterostichus melanarius, in relation to gut contents and prey densities, in insecticide treated and untreated spring barley. Entomol. Exp. Appl. 36, 23-30.

Chiverton, P.A. and Sotherton, N.W. 1991. The effects on beneficial arthropods of the exclusion of herbicides from cereal crop edges. J. App. Ecol. 28, 1027-1039.

Coll, M. and Guershon, M. 2002. Omnivory in terrestrial arthropods: mixing plant and prey diets. Ann. Rev. Entomo. 47, 267-297.

Costello, M.J. and Daane, K.M., 1998. Influence of ground cover on spider populations in a table grape vineyard. Ecol. Entomo. 23, 33-40.

Costello, M.J. and Daane, K.M., 2003. Spider and leafhopper (Erythroneura spp.) response to vineyard ground cover. Environ. Entomo. 32, 1085-1098.

De Cortazar, V. G., Cordova, C., and Pinto, M. 2005. Canopy structure and photosynthesis modeling of grapevines grown on an overhead trellis system in Chile. Austr. J. Grape Wine Res. 11, 328-338. 
Diamond, J. 1997. Book. Guns, germs and steel: the fates of human societies. New York: W. W. Norton.

Fischer, B.B., Yeary, E.A., and Marcroft, J.E. 2002. Principle of weed control, third edition. Chapter 3: Vegetation management systems. Thomson Publication, Fresno, CA 93791. Frampton, G.K. and Dorne, J.L. 2007. The effects on terrestrial invertebrates of reducing pesticide inputs in arable crop edges: a meta-analysis. J. App Ecol. 44, 362-373.

Gerowitt, B., Bertke, E., Hespelt, S.K., and Tute, C. 2003. Towards multifunctional agriculture - weeds as ecological goods? Weed Research. 43, 227-235.

Greenslade, P.J.M. 1964. Pitfall trapping as a method for studying populations of Carabidae (Coleoptera). J. Anim. Ecol. 33, 301-310.

Hembree, K.J. and Lanini, W.T. 2006. Weeds. UC IPM Pest Management Guidelines: Grape. University of California Agriculture and Natural Resources no. 3448, pp. 90-108.

Hummel, R.L., Walgenbach, J.F., Hoyt, G.D., and Kennedy, G.G. 2002. Effects of vegetable production system on epigeal arthropod populations. Agric. Ecosyst. Environ. 93, 177188.

Ingels, C. 1992. Technical brief: sustainable agriculture and grape production. Am. J. Enol. Vitic. 43, 296-298.

Ingels, C.A., Scow, K.M., Whisson, D.A., and Drenovsky, R.E. 2005. Effects of cover crops on grapevines, yield, juice composition, soil microbial ecology, and gopher activity. Am. J. Enol. Vitic. 56, 19-29.

Jorgensen, H.B, and Toft, S. 1997. Role of granivory and insectivory in the life cycle of the carabid beetle Amara similata. Ecological Entomology. 22, 7-15. 
Krohn, N. G. and Ferree, D. C. 2005. Effects of low-growing perennial ornamental groundcovers on the growth and fruiting of 'Seyval blanc' grapevines. Hort. Sci. 40, $561-568$.

Kromp, B. 1999. Carabid beetles in sustainable agriculture: a review on pest control efficacy, cultivation impacts and enhancement. Agric. Ecosyst. Environ. 74, 187-228.

Kulman, H.M. 1974. Comparative ecology of North America Carabidae with special reference to biological control (1). Entomophaga 7, 61-70.

Landis, D.A., Wratten, S.D., and Gurr, G.M., 2000. Habitat management to conserve natural enemies of arthropod pests in agriculture. Апnи. Rev. Entomol. 45, 175-201.

Leps. J, Brown, V.K., Diaz Len, T.A., et al. 2001. Separating the chance effect from other diversity effects in the functioning of plant communities. Oikos 92, 123-134.

Lindroth, C.H. 1974. Handbooks for the identification of British insects. IV. Part 2. Coleoptera: Carabidae. Royal Entomological Society, London, UK.

Lys, J.A. and Nentwig, W. 1992. Augmentation of beneficial arthropods by stripmanagement. Oecologia 92, 373-382.

Marshall, E.J.P., Brown, V.K., Boatman, N.D., Lutman, P.J., Sqiure, G.R., and Ward. L.K. 2003. The role of weed in supporting diversity within crop fields. Weed Research 43, $77-89$.

McCune, B. and Grace, J.B., 2002. Analysis of ecological communities. MjM Press, Gleneden Beach, OR, USA.

McCune, B. and Mefford, M.J., 1999. PC-ORD. Multivariate analysis of ecological data. Version 4. MjM Software Design, Gleneden Beach, OR, USA. 
Menalled, F.D., Marino, P.C., Renner, K.A., and Landis, D.A. 2000. Post-dispersal weed seed predation in Michigan crop fields as a function of agricultural landscape structure. Agric. Ecosyst. Environ. 77, 193-202.

Menalled, F.D., Lee, J.C., and Landis, D.A. 2001. Herbaceous filter strips in agroecosystems: implications for ground beetle (Coleoptera: Carabidae) conservation and invertebrate weed seed predation. The Great Lakes Entomologist 34, 77-91.

Menalled, F.D., Smith, R.G., Dauer, J.T., and Fox, T.B, 2007. Impact of agricultural management on carabid communities and weed seed predation. Agric. Ecosyst. Environ. 118, 49-54.

Monteiro, A. and Lopes. C.M. 2007. Influence of cover crop on water use and performance of vineyard in Mediterranean Portugal. Agric. Ecosyst. Environ. 121, 336-342.

National Weather Service. 2007. California, USA. http://www.cnrfc.noaa.gov/monthly_precip_2007.php

Nicholls, C.I., Parrella, M.P., and Altieri, M.A. 2000. Reducing the abundance of leafhoppers and thrips in a northern California organic vineyard through maintenance of full season flora diversity with summer cover crops. Agri Forest Entomol. 2, 107-113.

Norris, R.F. and Kogan, M., 2000. Interaction between weeds, arthropod pests, and their natural enemies in managed ecosystems. Weed Science 48, 94-158.

O’Neal, M.E., Zontek, E.L., Szendrei, Z., Landis, D.A., and Isaacs, R., 2005. Ground predator abundance affects prey removal in highbush blueberry (Vaccinium corymbosum) fields and can be altered by aisle ground covers. BioControl 50, 205-222.

Orr, D.B., Landis, D.A., Mutch, D.R., Manley, G.V., Stuby S.A., and King, R.L., 1997. Ground cover influence on the microclimate and Trichogramma (Hymenoptera: 
Trichogrammatidae) augmentation in seed corn production. Environmental Entomology 26, 433-438.

Purtauf, T., Roschewitz, I., Dauber, J., Thies, C., Tscharntke, T., and Wolters. V. 2005. Landscape context of organic and conventional farms: Influence on carabid beetles diversity. Agric. Ecosyst. Environ. 108, 165-174.

Sanguankeo, P.P., Leon, R.G. and Malone, J. 2009. Impact of weed management practices on grapevine growth and yield components. Weed Science 57, 103-107.

Saska, P. and Jarosik, V. 2001.Laboratory study of larval food requirement in nine species of Amara (Coleoptera: Carabidae). Plant Protection Sci. 37(3), 103-110.

Shelton, M.D. and Edwards, C.R. 1983.Effects of weeds on the diversity and abundance of insects in soybeans. Environmental Entomology 12, 296-298.

Smith, R.G. and Gross, K.L. 2007. Assembly of weed communities along a crop diversity gradient. J. App. Ecol. 44, 1046-1056.

Sosnoskie, L.M. Herms, C.P., and Cardina, J. 2006. Weed seedbank community composition in a 35-yr-old tillage and rotation experiment. Weed Science 54, 263-273.

Straub, C.S., Finke, D.L., and Snyder, W.E. 2008. Are the conservation of natural enemy biodiversity and biological control compatible goals? Biological Control 45(2), 225237.

Steinmaus, S., Elmore, C. L., Smith, R. J. et al. 2008. Mulched cover crops as an alternative to conventional weed management systems in vineyards. Weed Research 48, 273-281.

Thomas, M.B., Written, S.D., and Sotherton, N.W. 1991. Creation of 'island' habitats in farmland to manipulate populations of beneficial arthropods: predator densities and emigration. J. App. Ecol. 28, 906-917. 
Thomas, C.F.G. and Marshall, E.J.P., 1999. Arthropod abundance and diversity in differently vegetated margins of arable fields. Agric. Ecosyst. Environ. 72, 131-144.

Thomas, C.F.G., Brown, N.J., Kendall, D.A., 2006. Carabid movement and vegetation density: Implication for interpreting pitfall trap data from split-field trials. Agric. Ecosyst. Environ. 113, 51-61.

Troiano, J. and Garretson, C. 1998. Movement of simazine in runoff water from citrus orchard row middle as affected by mechanical incorporation, J. Environ. Qual. 27:488494.

United States Department of Agriculture: National Agricultural Statistics Service, 2007. http://www.nass.usda.gov/Statistics_by_State/California/Publications/Fruits_and_Nuts/ $\underline{\text { index_gab.asp }}$

Wade, J., Holzapfel, B., Degaris, K., Williams, D., and Keller, M. 2004. Nitrogen and water management strategies for wine-grape quality. Acta Hort. 640: 61-67.

Wissenger, S.A., 1997. Cyclic colonization in predictably ephemeral habitats: a template for biological control in annual crop systems. Biological Control 10, 4-15.

Wyss, E. 1996. The effects of artificial weed strips on diversity and abundance of the arthropod fauna in a Swiss experimental apple orchard. Agric. Ecosyst. Environ. 60, 47-59.

Zangger, A., Lys, J.A., and Nentwig, W., 1994. Increasing the availability of food and the reproduction of Poecilus cupreus in a cereal field by strip-management. Entomol. Exp. Appl. 71, 111-120. 


\section{Sources of Materials}

${ }^{1}$ Pellenc Tournesol 2250 AR, Pellenc America Inc., Santa Rosa, CA.

2 AccuPAR LP-80 light sensor, DECAGON Devices, Inc., Pullman, WA.

${ }^{3}$ WineScan FT 120, Foss Solutions, Eden Prairie, MN.

${ }^{4}$ Minitab 15, Minitab, Inc., State College, PA.

${ }^{5}$ PC-ORD 5.11. MjM Software Design, Gleneden Beach, OR, USA. 
Table 1. Species composition of the cover crop seeded in the berms in February of 2006 and 2007 in a Zinfandel vineyard in CA, USA.

\begin{tabular}{lccc}
\hline Species & \% Seed & $\begin{array}{c}\text { Life } \\
\text { Cycle }\end{array}$ & $\begin{array}{c}\text { Height } \\
\text { At maturity } \\
(\mathrm{cm})\end{array}$ \\
\hline Centaurea cyanus & 4.6 & Annual & 46 \\
Eschscholzia californica & 4.8 & Annual & 46 \\
Festuca rubra commutata & 32.8 & Perennial & 41 \\
Layia platyglossa & 1.5 & Annual & 30 \\
Lotus corniculatus & 7.6 & Perennial & 25 \\
Nemophila menziesii & 3.0 & Annual & 23 \\
Trifolium incarnatum & 7.0 & Annual & 76 \\
Trifolium repens & 13.9 & Perennial & 15 \\
Trifolium subterraneum & 18.2 & Annual & 20 \\
Vulpia microstachys & 6.6 & Annual & 51 \\
\hline
\end{tabular}



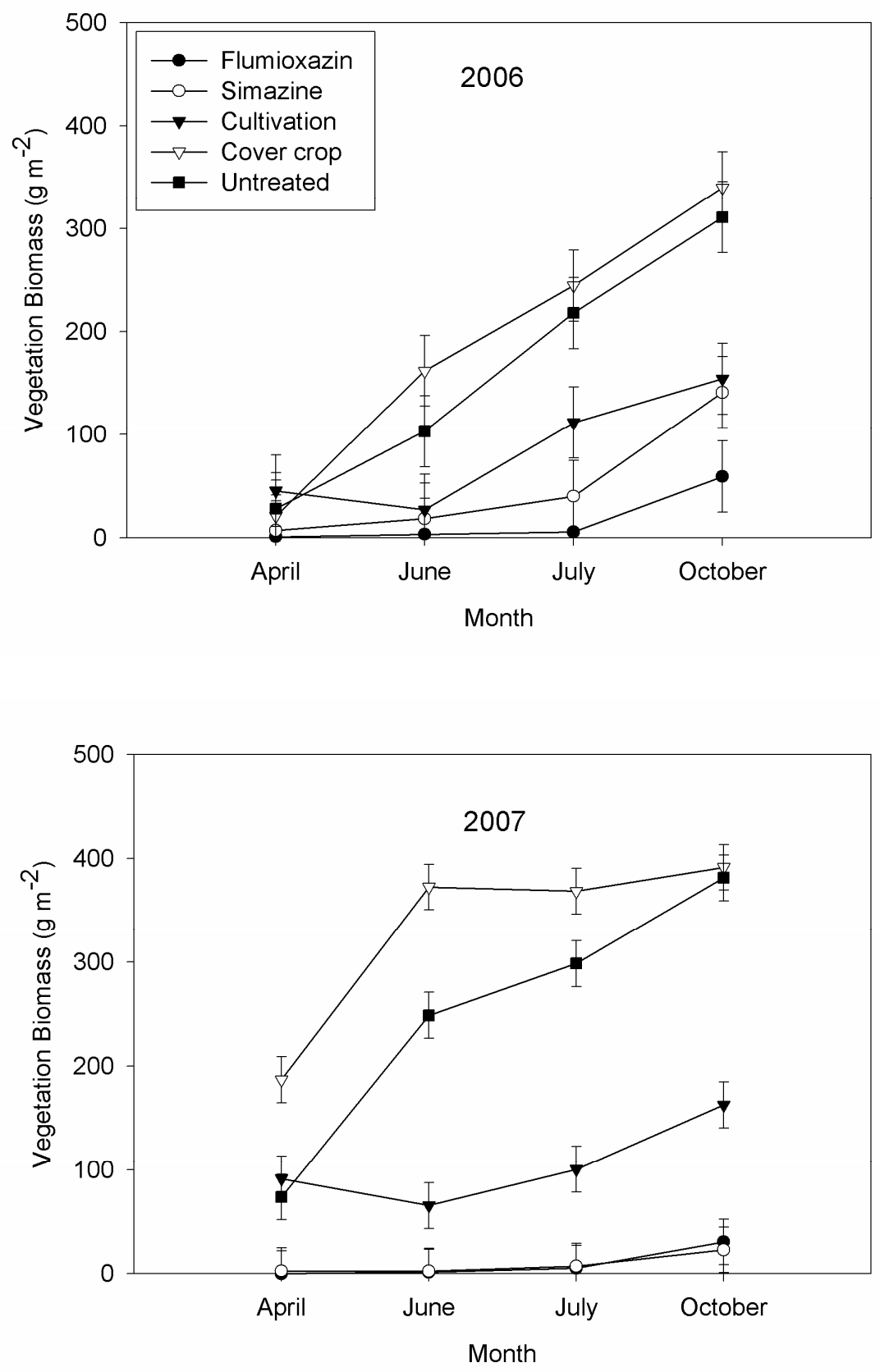

Figure 1. Vegetation biomass in five weed management tactics in a vineyard in CA, USA, in 2006 and 2007. Error bar represent 95\% confidence intervals for mean weed biomass. 
Table 2. Berm vegetation density including four functional groups in five vineyard weed management tactics in a Zinfandel vineyard in Central Coast California, USA.

\begin{tabular}{|c|c|c|c|c|c|c|c|c|c|c|}
\hline \multirow[b]{3}{*}{ Treatment } & \multicolumn{10}{|c|}{ Vegetation Density } \\
\hline & \multicolumn{2}{|c|}{ Total } & \multicolumn{2}{|c|}{$\begin{array}{l}\text { Annual Grass } \\
\text { Species }\end{array}$} & \multicolumn{2}{|c|}{$\begin{array}{c}\text { Annual } \\
\text { Broadleaf } \\
\text { Species }\end{array}$} & \multicolumn{2}{|c|}{$\begin{array}{c}\text { Perennial Grass } \\
\text { Species }\end{array}$} & \multicolumn{2}{|c|}{$\begin{array}{c}\text { Perennial } \\
\text { Broadleaf } \\
\text { Species }\end{array}$} \\
\hline & 2006 & 2007 & 2006 & 2007 & 2006 & 2007 & 2006 & 2007 & 2006 & 2007 \\
\hline & \multicolumn{2}{|c|}{ Plants $\mathrm{m}^{-2}$} & \multicolumn{2}{|c|}{$\%$ of total } & \multicolumn{2}{|c|}{$\%$ of total } & \multicolumn{2}{|c|}{$\%$ of total } & \multicolumn{2}{|c|}{$\%$ of total } \\
\hline Flumioxazin & $48.2 \mathrm{a}$ & $3.7 \mathrm{a}$ & $\begin{array}{c}69.5 \\
\mathrm{a}\end{array}$ & $44.0 \mathrm{a}$ & $25.6 \mathrm{a}$ & $42.1 \mathrm{a}$ & $4.9 \mathrm{a}$ & $1.0 \mathrm{a}$ & $0.1 \mathrm{a}$ & $12.9 \mathrm{a}$ \\
\hline Simazine & $64.4 a$ & $4.5 \mathrm{a}$ & $\begin{array}{c}60.3 \\
a\end{array}$ & $50.2 \mathrm{a}$ & $\begin{array}{c}34.6 \\
a b\end{array}$ & $\begin{array}{c}35.8 \\
\text { ac }\end{array}$ & $4.7 \mathrm{a}$ & $7.5 \mathrm{ab}$ & $0.5 \mathrm{a}$ & $6.5 \mathrm{a}$ \\
\hline Cultivation & $196.6 \mathrm{~b}$ & $\begin{array}{c}129.9 \\
b\end{array}$ & $\begin{array}{c}35.8 \\
\mathrm{~b}\end{array}$ & $\begin{array}{c}28.0 \\
\mathrm{ab}\end{array}$ & $\begin{array}{c}45.9 \\
\mathrm{bc}\end{array}$ & $\begin{array}{c}50.4 \\
\mathrm{ab}\end{array}$ & $16.9 \mathrm{~b}$ & $19.6 \mathrm{~b}$ & $1.4 \mathrm{a}$ & $2.1 \mathrm{a}$ \\
\hline Cover crop & $278.9 c$ & $\begin{array}{c}256.3 \\
c\end{array}$ & $8.5 \mathrm{c}$ & $14.1 \mathrm{~b}$ & $32.9 \mathrm{a}$ & $21.5 \mathrm{c}$ & $31.5 \mathrm{c}$ & $38.7 \mathrm{c}$ & $\begin{array}{c}27.1 \\
\text { b }\end{array}$ & $25.8 \mathrm{~b}$ \\
\hline Untreated & $165.9 \mathrm{~b}$ & $\begin{array}{c}207.0 \\
\text { c }\end{array}$ & $\begin{array}{c}39.6 \\
b\end{array}$ & $\begin{array}{c}21.8 \\
\mathrm{ab}\end{array}$ & $48.8 \mathrm{c}$ & $57.3 \mathrm{~b}$ & $8.8 \mathrm{a}$ & $\begin{array}{c}18.6 \\
\mathrm{ab}\end{array}$ & $2.8 \mathrm{a}$ & $2.3 \mathrm{a}$ \\
\hline
\end{tabular}

Samples were obtained from $0.25 \mathrm{~m}^{2}$ quadrants between March and October 2006-7. Values are means $(n=4)$. Within a column numbers followed by the same letter are not significantly different based on HSD test $(\alpha=0.05)$. 
Table 3. Berm vegetation biomass including four functional groups in five vineyard weed management tactics in a Zinfandel vineyard in Central Coast California, USA.

\begin{tabular}{|c|c|c|c|c|c|c|c|c|c|c|}
\hline \multirow[b]{3}{*}{ Treatment } & \multicolumn{10}{|c|}{ Vegetation Biomass } \\
\hline & \multicolumn{2}{|c|}{ Total } & \multicolumn{2}{|c|}{$\begin{array}{c}\text { Annual Grass } \\
\text { Species }\end{array}$} & \multicolumn{2}{|c|}{$\begin{array}{c}\text { Annual } \\
\text { Broadleaf } \\
\text { Species }\end{array}$} & \multicolumn{2}{|c|}{$\begin{array}{c}\text { Perennial Grass } \\
\text { Species }\end{array}$} & \multicolumn{2}{|c|}{$\begin{array}{c}\text { Perennial } \\
\text { Broadleaf } \\
\text { Species }\end{array}$} \\
\hline & 2006 & 2007 & 2006 & 2007 & 2006 & 2007 & 2006 & 2007 & 2006 & 2007 \\
\hline & \multicolumn{2}{|c|}{$\mathrm{g} \mathrm{m}^{-2}$} & \multicolumn{2}{|c|}{$\%$ of total } & \multicolumn{2}{|c|}{$\%$ of total } & \multicolumn{2}{|c|}{$\%$ of total } & \multicolumn{2}{|c|}{$\%$ of total } \\
\hline Flumioxazin & $17.3 \mathrm{a}$ & $9.2 \mathrm{a}$ & $72.9 \mathrm{a}$ & $49.3 \mathrm{a}$ & $24.1 \mathrm{a}$ & $49.1 \mathrm{a}$ & $3.0 \mathrm{a}$ & $0 \mathrm{a}$ & $0.1 \mathrm{a}$ & $1.6 \mathrm{a}$ \\
\hline Simazine & $51.5 \mathrm{a}$ & $8.1 \mathrm{a}$ & $\begin{array}{c}27.1 \\
b\end{array}$ & $46.6 \mathrm{a}$ & $59.3 \mathrm{a}$ & $32.7 \mathrm{~b}$ & $\begin{array}{c}11.9 \\
\mathrm{ab}\end{array}$ & $17.0 \mathrm{a}$ & $1.7 \mathrm{a}$ & $3.7 \mathrm{a}$ \\
\hline Cultivation & $87.4 \mathrm{a}$ & $\begin{array}{c}105.1 \\
\mathrm{~b}\end{array}$ & $\begin{array}{c}33.4 \\
\text { b }\end{array}$ & $27.4 \mathrm{ab}$ & $49.5 \mathrm{a}$ & $58.3 \mathrm{a}$ & $\begin{array}{c}10.2 \\
\mathrm{ab}\end{array}$ & $11.2 \mathrm{a}$ & $7.0 \mathrm{a}$ & $3.1 \mathrm{a}$ \\
\hline Cover crop & $194.1 \mathrm{~b}$ & $\begin{array}{c}335.2 \\
\mathrm{c}\end{array}$ & $0.6 \mathrm{~b}$ & $1.9 \mathrm{~b}$ & $43.3 \mathrm{a}$ & $12.3 \mathrm{~b}$ & $\begin{array}{c}23.1 \\
\mathrm{ab}\end{array}$ & $31.6 \mathrm{~b}$ & $32.9 \mathrm{~b}$ & $54.3 \mathrm{~b}$ \\
\hline Untreated & $187.5 \mathrm{~b}$ & $\begin{array}{c}249.8 \\
\text { d }\end{array}$ & $4.9 \mathrm{~b}$ & $13.0 \mathrm{~b}$ & $\begin{array}{c}82.8 \\
\text { b }\end{array}$ & $74.5 \mathrm{a}$ & $\begin{array}{c}10.0 \\
\mathrm{ab}\end{array}$ & $8.9 \mathrm{a}$ & $2.3 \mathrm{a}$ & $3.6 \mathrm{a}$ \\
\hline
\end{tabular}

Values are means $(n=4)$.Within a column numbers followed by the same letter are not significantly different based on HSD test $(\alpha=0.05)$. 

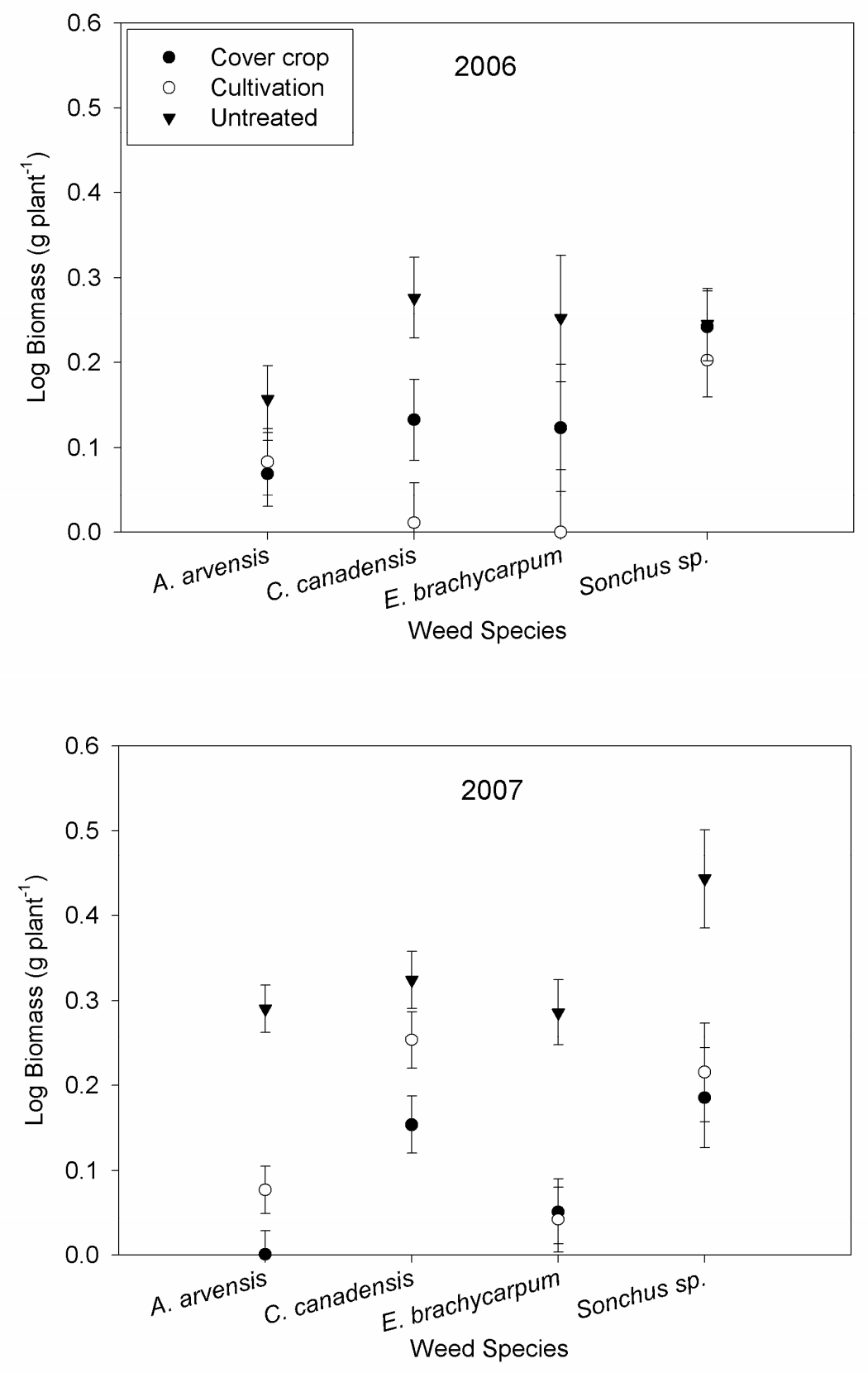

Figure 2. Weed biomass per plant of Anagallis arvensis, Conyza canadensis, Epilobium brachycarpum and Sonchus sp. for cover crop, cultivation and untreated control. Error bars represent $95 \%$ confidence intervals for mean weed biomass. 
Table 4. Percentage light interception of grapevine canopy And dormant grapevine cane weight biomass in five vineyard weed management tactics in a Zinfandel vineyard in Central Coast California, USA.

\begin{tabular}{|c|c|c|c|c|}
\hline \multirow[b]{3}{*}{ Treatment } & \multicolumn{4}{|c|}{ Grapevine Growth } \\
\hline & \multicolumn{2}{|c|}{$\begin{array}{l}\text { Canopy light } \\
\text { interception }\end{array}$} & \multicolumn{2}{|c|}{ Cane weight } \\
\hline & 2006 & 2007 & 2006 & 2007 \\
\hline & \multicolumn{2}{|c|}{$\begin{array}{l}\% \text { light } \\
\text { intercepted vine }{ }^{-1}\end{array}$} & \multicolumn{2}{|c|}{$\mathrm{kg}$ vine $^{-1}$} \\
\hline Flumioxazin & $68 \mathrm{a}$ & $68 \mathrm{a}$ & $1.61 \mathrm{a}$ & $1.59 \mathrm{a}$ \\
\hline Simazine & $69 a$ & $68 \mathrm{a}$ & $1.82 \mathrm{a}$ & $1.43 \mathrm{a}$ \\
\hline Cultivation & $59 \mathrm{~b}$ & $57 \mathrm{~b}$ & $1.53 \mathrm{a}$ & $0.66 \mathrm{~b}$ \\
\hline Cover crop & $57 \mathrm{~b}$ & $48 \mathrm{c}$ & $1.48 \mathrm{a}$ & $0.37 \mathrm{c}$ \\
\hline Untreated & $52 \mathrm{~b}$ & $42 \mathrm{~d}$ & $1.08 \mathrm{~b}$ & $0.37 \mathrm{c}$ \\
\hline
\end{tabular}

Values are means $(n=4)$. Within a column numbers followed by the same letter are not significantly different based on HSD test ( $\alpha=0.05)$. 
Table 5. Grapevine fruit weight, cluster weight, number of cluster per vine, number of berry per cluster, and berry weight in five vineyard weed management tactics at a Zinfandel vineyard in Central Coast California, USA.

\begin{tabular}{|c|c|c|c|c|c|c|c|c|c|c|}
\hline \multirow[b]{3}{*}{ Treatment } & \multicolumn{10}{|c|}{ Yield Characteristics } \\
\hline & \multicolumn{2}{|c|}{ Fruit weight } & \multicolumn{2}{|c|}{ Cluster weight } & \multicolumn{2}{|c|}{$\begin{array}{l}\text { Number of } \\
\text { cluster }\end{array}$} & \multicolumn{2}{|c|}{$\begin{array}{c}\text { Number of } \\
\text { berry }\end{array}$} & \multicolumn{2}{|c|}{ Berry weight } \\
\hline & 2006 & 2007 & 2006 & 2007 & 2006 & 2007 & 2006 & 2007 & 2006 & 2007 \\
\hline & \multicolumn{2}{|c|}{$\mathrm{kg}_{\text {vine }}{ }^{-1}$} & \multicolumn{2}{|c|}{ g cluster $^{-1}$} & \multicolumn{2}{|c|}{ Number vine $^{-1}$} & \multicolumn{2}{|c|}{${ }_{1}^{\text {Number cluster }}{ }^{-}$} & \multicolumn{2}{|c|}{ g berry $^{-1}$} \\
\hline Flumioxazin & $21.5 \mathrm{a}$ & $15.2 \mathrm{a}$ & $262 \mathrm{a}$ & $240 \mathrm{a}$ & $43 \mathrm{a}$ & $40 \mathrm{a}$ & $249 \mathrm{a}$ & $193 \mathrm{ab}$ & $1.4 \mathrm{a}$ & $1.7 \mathrm{a}$ \\
\hline Simazine & $21.9 \mathrm{a}$ & $15.6 \mathrm{a}$ & $294 \mathrm{a}$ & $253 \mathrm{a}$ & $39 \mathrm{ab}$ & $41 \mathrm{a}$ & $221 \mathrm{ab}$ & $205 \mathrm{a}$ & $1.5 \mathrm{a}$ & $1.7 \mathrm{a}$ \\
\hline Cultivation & $23.8 \mathrm{a}$ & $12.0 \mathrm{~b}$ & $273 \mathrm{a}$ & $195 \mathrm{~b}$ & $46 \mathrm{a}$ & $35 \mathrm{~b}$ & $214 \mathrm{~b}$ & $169 \mathrm{~b}$ & $1.3 \mathrm{a}$ & $1.7 \mathrm{a}$ \\
\hline Cover crop & $18.9 \mathrm{~b}$ & $8.5 \mathrm{c}$ & $276 \mathrm{a}$ & $146 \mathrm{c}$ & $36 \mathrm{~b}$ & $33 \mathrm{~b}$ & $212 \mathrm{~b}$ & $139 \mathrm{c}$ & $1.4 \mathrm{a}$ & $1.4 \mathrm{~b}$ \\
\hline Untreated & $16.4 \mathrm{~b}$ & $8.0 \mathrm{c}$ & $221 \mathrm{~b}$ & $135 \mathrm{c}$ & $39 \mathrm{ab}$ & $33 \mathrm{~b}$ & $187 \mathrm{~b}$ & $137 \mathrm{c}$ & $1.0 \mathrm{~b}$ & $1.3 \mathrm{c}$ \\
\hline
\end{tabular}

Values are means $(n=4)$. Within a column numbers followed by the same letter are not significantly different based on HSD test $(\alpha=0.05)$. 
Table 6. Grape juice parameters test results for Brix degree, Titratable Acidity, and $\mathrm{pH}$ in five vineyard weed management tactics at a Zinfandel vineyard in Central Coast California, USA.

$$
\text { Juice Quality Parameters }
$$

\begin{tabular}{|c|c|c|c|c|c|c|}
\hline \multirow[b]{2}{*}{ Treatment } & \multicolumn{2}{|c|}{ Brix } & \multicolumn{2}{|c|}{ TA } & \multicolumn{2}{|c|}{$\mathrm{pH}$} \\
\hline & 2006 & 2007 & 2006 & 2007 & 2006 & 2007 \\
\hline & \multicolumn{6}{|c|}{$\mathrm{g}$ tartaric $/ 100 \mathrm{ml}$} \\
\hline Flumioxazin & $22.57 \mathrm{a}$ & $24.3 \mathrm{a}$ & $0.56 \mathrm{a}$ & $0.53 \mathrm{a}$ & $3.38 \mathrm{a}$ & $3.31 \mathrm{a}$ \\
\hline Simazine & $23.53 \mathrm{a}$ & $23.7 \mathrm{a}$ & $0.56 \mathrm{a}$ & $0.57 \mathrm{a}$ & $3.37 \mathrm{a}$ & $3.29 \mathrm{a}$ \\
\hline Cultivation & $20.60 \mathrm{~b}$ & $24.3 \mathrm{a}$ & $0.60 \mathrm{a}$ & $0.54 \mathrm{a}$ & $3.30 \mathrm{a}$ & $3.45 \mathrm{a}$ \\
\hline Cover crop & $21.87 \mathrm{a}$ & $25.4 \mathrm{a}$ & $0.57 \mathrm{a}$ & $0.49 \mathrm{a}$ & $3.33 \mathrm{a}$ & $3.44 \mathrm{a}$ \\
\hline Untreated & $23.33 \mathrm{a}$ & $24.8 \mathrm{a}$ & $0.52 \mathrm{a}$ & $0.48 \mathrm{a}$ & $3.37 \mathrm{a}$ & $3.45 \mathrm{a}$ \\
\hline
\end{tabular}

Values are mean $(n=4)$. Within a column numbers followed by the same letter are not significantly different based on HSD test $(\alpha=0.05)$.. 
Table 7. Plant density, richness $(R)$, evenness $(E)$, and Shannon-Weiner diversity index $\left(H^{\prime}\right)$ in five weed management treatments in a Zinfandel vineyard in Central Coast California, USA, in 2006 and $2007^{*}$.

\begin{tabular}{|c|c|c|c|c|c|}
\hline Parameters & Flumioxazin & Simazine & Cultivation & Cover-crop & Control \\
\hline \multicolumn{6}{|c|}{ Density (plants $\mathrm{m}^{-2}$ ) } \\
\hline 2006 & $48.2 \mathrm{a}^{\dagger}$ & $64.4 \mathrm{a}$ & $196.6 \mathrm{~b}$ & $278.9 \mathrm{c}$ & $165.9 \mathrm{~b}$ \\
\hline 2007 & $3.7 \mathrm{a}$ & $4.5 \mathrm{a}$ & $129.9 \mathrm{~b}$ & $256.3 \mathrm{~d}$ & $207.0 \mathrm{c}$ \\
\hline \multicolumn{6}{|l|}{$R$} \\
\hline 2006 & $15 \mathrm{a}$ & $20 \mathrm{a}$ & $26 \mathrm{~b}$ & $31 \mathrm{~b}$ & $28 \mathrm{~b}$ \\
\hline 2007 & $6 \mathrm{a}$ & $8 \mathrm{a}$ & $24 \mathrm{~b}$ & $24 \mathrm{~b}$ & $25 \mathrm{~b}$ \\
\hline \multicolumn{6}{|l|}{ E } \\
\hline 2006 & $0.2 \mathrm{a}$ & $0.3 \mathrm{~b}$ & $0.8 \mathrm{c}$ & $0.8 \mathrm{c}$ & $0.8 \mathrm{c}$ \\
\hline 2007 & $0.2 \mathrm{a}$ & $0.2 \mathrm{a}$ & $0.8 \mathrm{~b}$ & $0.8 \mathrm{~b}$ & $0.8 \mathrm{~b}$ \\
\hline \multicolumn{6}{|l|}{$H^{\prime}$} \\
\hline 2006 & $0.2 \mathrm{a}$ & $0.3 \mathrm{a}$ & $1.3 \mathrm{~b}$ & $1.5 \mathrm{c}$ & $1.4 \mathrm{c}$ \\
\hline 2007 & $0.1 \mathrm{a}$ & $0.1 \mathrm{a}$ & $1.3 \mathrm{~b}$ & $1.6 \mathrm{c}$ & $1.7 \mathrm{c}$ \\
\hline
\end{tabular}

"Samples were obtained from $0.25 \mathrm{~m}^{2}$ quadrants between March and October.

${ }^{\dagger}$ Within a row, numbers followed by the same letter are not significantly different $(P \geq 0.05$, HSD test). 
Table 8. Terrestrial arthropod activity-density, richness $(R)$, evenness $(E)$, and Shannon-Weiner diversity index $\left(H^{\prime}\right)$ in five weed management treatments in a Zinfandel vineyard in Central Coast California, USA in 2006 and 2007*.

\begin{tabular}{|c|c|c|c|c|c|}
\hline Parameters & Flumioxazin & Simazine & Cultivation & Cover-crop & Control \\
\hline \multicolumn{6}{|c|}{ Activity-density } \\
\hline \multicolumn{6}{|c|}{ Terrestrial arthropods } \\
\hline 2006 & $68.9 \mathrm{a}^{\dagger}$ & $61.5 \mathrm{a}$ & $59.7 \mathrm{a}$ & $50.9 \mathrm{a}$ & $63.7 \mathrm{a}$ \\
\hline 2007 & $53.2 \mathrm{a}$ & $65.0 \mathrm{ab}$ & $114.7 \mathrm{c}$ & $96.2 \mathrm{bc}$ & $122.3 \mathrm{c}$ \\
\hline \multicolumn{6}{|c|}{ Tanystoma maculicolle } \\
\hline 2006 & $0.68 \mathrm{a}$ & $0.50 \mathrm{ab}$ & $0.24 \mathrm{~b}$ & $0.39 \mathrm{ab}$ & $0.19 \mathrm{~b}$ \\
\hline 2007 & $0.21 \mathrm{a}$ & $0.31 \mathrm{ab}$ & $0.16 \mathrm{a}$ & $0.59 \mathrm{~b}$ & $0.18 \mathrm{a}$ \\
\hline \multicolumn{6}{|c|}{ Calathus ruficollis } \\
\hline 2006 & $0.18 \mathrm{ac}$ & $0.25 \mathrm{a}$ & $0.31 \mathrm{~b}$ & $0.40 \mathrm{~b}$ & $0.14 \mathrm{ac}$ \\
\hline 2007 & $0.25 \mathrm{a}$ & $0.33 \mathrm{a}$ & $0.35 \mathrm{a}$ & $1.20 \mathrm{~b}$ & $0.41 \mathrm{a}$ \\
\hline \multicolumn{6}{|l|}{$R$} \\
\hline 2006 & $20.3 \mathrm{a}$ & $20.0 \mathrm{a}$ & $23.3 \mathrm{ab}$ & $30.3 \mathrm{c}$ & $27.3 \mathrm{bc}$ \\
\hline 2007 & $17.8 \mathrm{a}$ & $16.8 \mathrm{a}$ & $23.3 \mathrm{~b}$ & $24.3 \mathrm{~b}$ & $23.0 \mathrm{~b}$ \\
\hline \multicolumn{6}{|l|}{ E } \\
\hline 2006 & $0.5 \mathrm{a}$ & $0.5 \mathrm{a}$ & $0.5 \mathrm{a}$ & $0.6 \mathrm{a}$ & $0.5 \mathrm{a}$ \\
\hline 2007 & $0.7 \mathrm{a}$ & $0.7 \mathrm{a}$ & $0.7 \mathrm{a}$ & $0.7 \mathrm{a}$ & $0.7 \mathrm{a}$ \\
\hline \multicolumn{6}{|l|}{$H^{\prime}$} \\
\hline 2006 & $0.8 \mathrm{a}$ & $0.8 \mathrm{a}$ & $0.9 \mathrm{ab}$ & $1.0 \mathrm{~b}$ & $0.8 \mathrm{a}$ \\
\hline 2007 & $1.0 \mathrm{~b}$ & $0.9 \mathrm{a}$ & $1.1 \mathrm{ab}$ & $1.3 \mathrm{c}$ & $1.2 \mathrm{bc}$ \\
\hline
\end{tabular}

*Samples were obtained using pitfall traps between March and October.

${ }^{\dagger}$ Within a row numbers followed by the same letter are not significantly different $(P \geq 0.05$, HSD test). 
Table 9. Regression analyses of arthropod diversity $\left(H^{\prime}\right.$ arthro $)$ and plant density $\left(\mathrm{N}_{\text {plant }}\right)$ and diversity $\left(H_{\text {plant }}\right)$ observed in a Zinfandel vineyard in Central Coast California, USA, in 2006 and $2007^{*}$.

\begin{tabular}{ccccccc}
\hline$y$ & $x$ & Year & slope & intercept & $r^{2}$ & P value \\
\hline$H_{\text {plant }}^{\prime}$ & $\mathrm{N}_{\text {plant }}$ & 2006 & 0.190 & 0.356 & 0.80 & $<0.001$ \\
& & 2007 & 0.027 & 0.203 & 0.90 & $<0.001$ \\
$H_{\text {arthro }}^{\prime}$ & $\mathrm{N}_{\text {plant }}$ & 2006 & 0.005 & 0.872 & 0.55 & 0.002 \\
& & & & & & \\
$H_{\text {arthro }}^{\prime}$ & $H^{\prime}{ }_{\text {plant }}$ & 2007 & 0.002 & 0.758 & 0.36 & 0.008 \\
& & 0.332 & 0.415 & 0.42 & 0.020 \\
& & 2007 & 0.185 & 0.918 & 0.64 & $<0.001$
\end{tabular}

*The overall relationship between arthropod and vegetation diversity each year was obtained combining the data of all treatments. 
Table 10. Pearson and Kendall correlation of arthropod communities with the first 3 axes of NMS ordination for 2006 and $2007^{*}$.

\begin{tabular}{lccccccccc}
\hline Variable & \multicolumn{2}{c}{ Axis 1 } & & \multicolumn{3}{c}{ Axis 2} & & \multicolumn{2}{c}{ Axis 3 } \\
\cline { 2 - 3 } \cline { 7 - 8 } & 2006 & 2007 & & 2006 & 2007 & & 2006 & 2007 \\
\hline Plant density & 0.26 & 0.36 & & -0.10 & -0.44 & & 0.77 & -0.81 \\
Plant species richness & 0.12 & 0.17 & & -0.07 & -0.59 & & 0.86 & -0.81 \\
Plant Evenness & -0.08 & 0.03 & & -0.18 & 0.27 & & 0.75 & 0.54 \\
Plant Diversity & -0.02 & 0.13 & & -0.18 & -0.59 & & 0.79 & -0.74 \\
& & & & & & & & \\
Arthropod activity-density & -0.19 & 0.47 & & -0.08 & 0.04 & & -0.58 & -0.65 \\
Arthropod species richness & -0.19 & 0.31 & & -0.13 & -0.57 & & 0.63 & -0.59 \\
Arthropod Evenness & 0.39 & -0.34 & & 0.33 & -0.76 & & 0.58 & -0.41 \\
Arthropod Diversity & 0.44 & -0.24 & & 0.16 & -0.82 & & 0.63 & -0.52 \\
\hline
\end{tabular}

${ }^{*} \mathrm{~N}=15$, Species $=36$ in 2006. $\mathrm{N}=17$, Species $=42$ in 2007. 


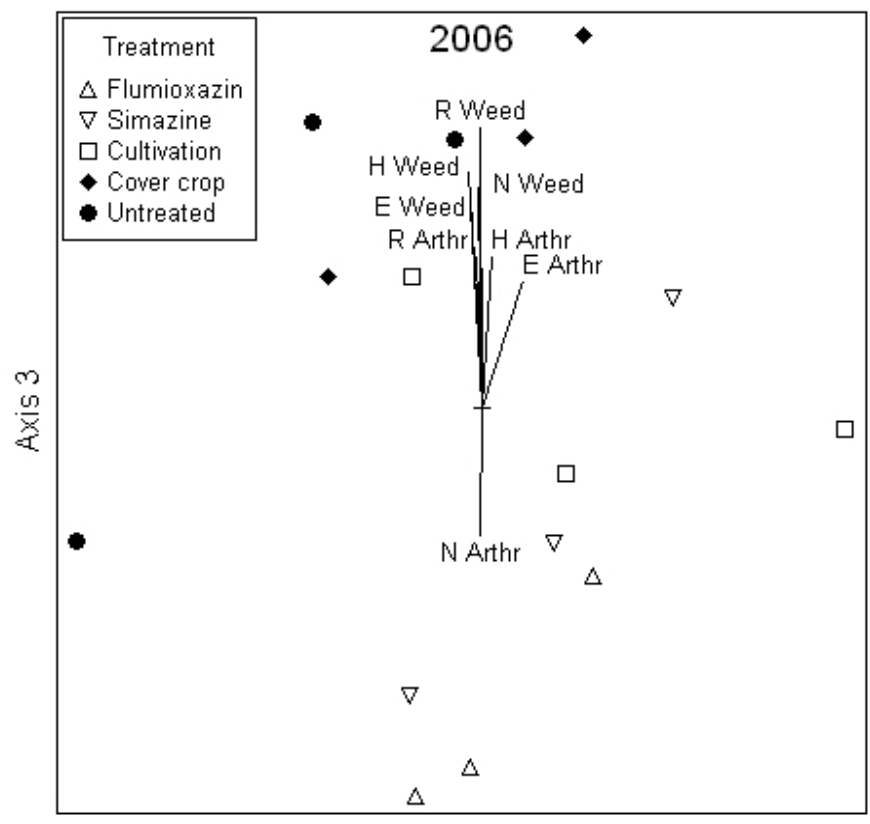

Axis 2

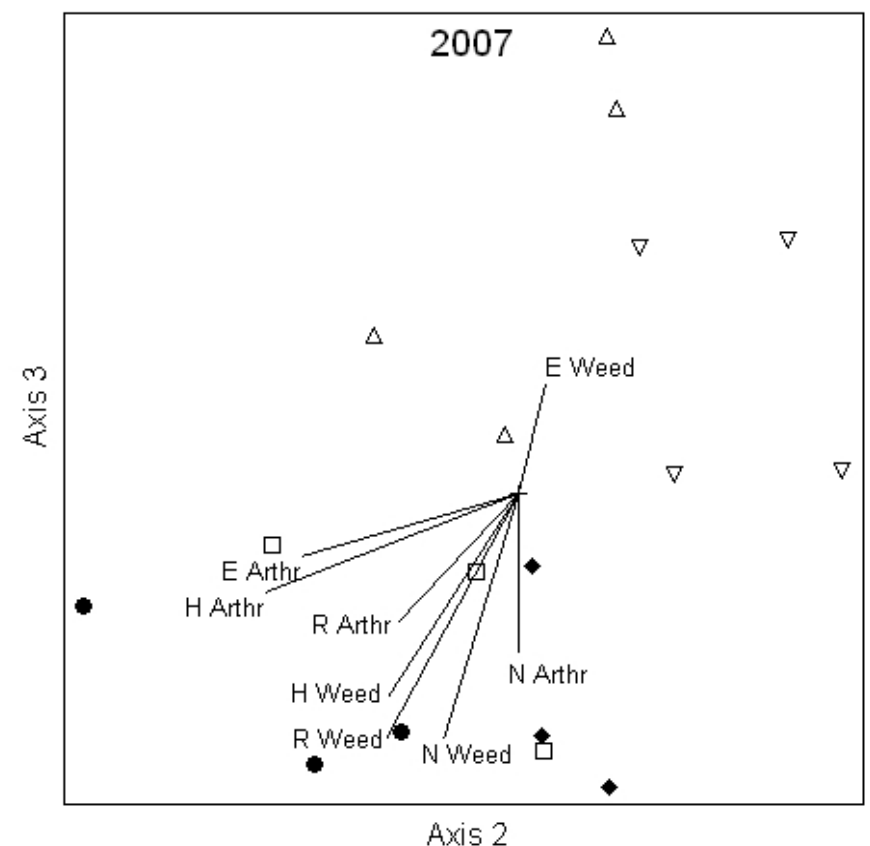

Axis 2

Figure 3. Nonmetric Multidimentional Scaling ordination showing distinct arthropod community compositions between herbicide and non-herbicide treatments including relationships to species richness $(R)$, evenness $(E)$ and diversity $(H)$ for arthropods $($ Arthr) and plants (Plant) in 2006 and 2007. Monte Carlo Test axis $2(P=0.058$ for $2006 ; P=0.048$ for 2007$)$ and axis $3(P=0.019$ for 2006; $P=0.048$ for 2007 . 
Table 11. Multi-Response Permutation Procedures (MRPP) for multivariate pairwise comparison of arthropod community composition between weed management treatments in 2006 and 2007.

\begin{tabular}{|c|c|c|}
\hline \multirow[t]{2}{*}{ Treatment Comparison } & \multicolumn{2}{|c|}{$P$-value } \\
\hline & 2006 & 2007 \\
\hline Flumioxazin vs. Cover crop & 0.00 & 0.02 \\
\hline Flumioxazin vs. Cultivation & 0.09 & 0.05 \\
\hline Flumioxazin vs. Simazine & 0.16 & 0.20 \\
\hline Flumioxazin vs. Control & 0.01 & 0.02 \\
\hline Cover crop vs. Cultivation & 0.17 & 0.13 \\
\hline Cover crop vs. Simazine & 0.01 & 0.01 \\
\hline Cover crop vs. Control & 0.02 & 0.03 \\
\hline Cultivation vs. Simazine & 0.12 & 0.02 \\
\hline Cultivation vs. Control & 0.45 & 0.21 \\
\hline Simazine vs. Control & 0.02 & 0.01 \\
\hline
\end{tabular}


Table 12. Percentage of predation shown by two carabid species on the seeds of eight weed species under laboratory conditions.

\begin{tabular}{lcc}
\hline \multirow{2}{*}{ Weed Species } & \multicolumn{2}{c}{ Carabid species } \\
\cline { 2 - 3 } & Tanystoma maculicolle & Calathus ruficollis \\
\hline Amaranthus retroflexus & 0 & 0 \\
Anagallis arvensis & 0 & 0 \\
Brassica nigra & $33.1(6.3) \mathrm{a}^{*}$ & $22.8(4.3) \mathrm{a}$ \\
Capsella bursa-pastoris & $41.4(11.0) \mathrm{a}$ & $63.6(9.1) \mathrm{b}$ \\
Eragrostis spp. & 0 & 0 \\
Malva parviflora & 0 & 0 \\
Picris echioides & 0 & 0 \\
Sonchus oleraceuos & 0 & 0 \\
\hline
\end{tabular}

*Values are mean \pm 1 S.E. $(n=12)$. Within a row numbers followed by the same letter are not significantly different at $P \geq 0.05$ (paired t-test). 
Table 13. Percentage of weed seed removed from seed cards by arthropods in a Zinfandel vineyard in Central Coast California, USA, in June and August, 2007*.

\begin{tabular}{lccccc}
\hline Species & Flumioxazin & Simazine & Cultivation & Cover-crop & Control \\
\hline June & & & & & \\
Brassica nigra & $3.5 \mathrm{a}^{\dagger}$ & $4.7 \mathrm{a}$ & $7.6 \mathrm{a}$ & $20.0 \mathrm{~b}$ & $16.9 \mathrm{~b}$ \\
Capsella bursa-pastoris & $5.4 \mathrm{a}$ & $3.9 \mathrm{a}$ & $5.4 \mathrm{a}$ & $11.8 \mathrm{~b}$ & $10.0 \mathrm{~b}$ \\
& & & & & \\
August & $14.0 \mathrm{a}$ & $13.8 \mathrm{a}$ & $20.0 \mathrm{ab}$ & $29.4 \mathrm{bc}$ & $40.6 \mathrm{c}$ \\
Brassica nigra & $10.1 \mathrm{a}$ & $9.4 \mathrm{a}$ & $18.3 \mathrm{~b}$ & $19.7 \mathrm{~b}$ & $16.9 \mathrm{~b}$ \\
Capsella bursa-pastoris &
\end{tabular}

"Samples were obtained from seed cards placed in the berm for 48 hours. Data from the exclusion cage and control are presented combined.

${ }^{\dagger}$ Within a row numbers followed by the same letter are not significantly different $(P \geq 0.05$, HSD test). 
Appendix A. List of arthropod species found in pitfall traps for each weed management treatment in a Zinfandel vineyard Central Coast California, USA.

\begin{tabular}{|c|c|c|c|c|c|c|c|}
\hline Family & Scientific name & Authur & Chateau & azine $\mathrm{C}$ & vation $\mathrm{C}$ & crop & oce \\
\hline Entomobryidae & Entomobrya sp. & $*$ & 6989 & 7407 & 10113 & 7901 & $104^{\prime}$ \\
\hline Formicidae & Solenopsis xyloni & McCook & 897 & 827 & 1333 & 1260 & \\
\hline Corinnidae & Trachelas pacificus & Chamberlin \& Ivie & 286 & 324 & 390 & 487 & \\
\hline Anthicidae & Formicilla munda & LeConte & 79 & 58 & 155 & 136 & \\
\hline Armadilliidae & Armadillidium vulgare & Brandt & 84 & 61 & 74 & 149 & \\
\hline Staphylinidae & Gabrius sp. & $*$ & 52 & 28 & 71 & 100 & \\
\hline Tenebrionidae & Blapstinus pratensis & LeConte & 71 & 62 & 56 & 71 & \\
\hline Carabidae & Dromius nigrinus & Mannerheim & 62 & 65 & 81 & 54 & \\
\hline Carabidae & Agonum maculicolle & Dejean & 57 & 54 & 25 & 61 & \\
\hline Carabidae & Calathus ruficollis & Dejean & 20 & 32 & 34 & 93 & \\
\hline Scolopendridae & Scolopendra polymorpha & Wood & 36 & 39 & 44 & 36 & \\
\hline Forficulidae & Forficula auricularia & Linnaeus & 29 & 34 & 30 & 35 & \\
\hline Carabidae & Dicherius dilatatus & Dejean & 21 & 22 & 25 & 25 & \\
\hline Carabidae & Carabus apricarius & Paykull & 17 & 15 & 16 & 21 & \\
\hline Gryllacrididae & Ceuthophilus sp. & Scudder & 12 & 8 & 13 & 19 & \\
\hline Carabidae & Dicherius piceus & Menetries & 4 & 8 & 12 & 18 & \\
\hline Carabidae & Amara californica & Dejean & 8 & 8 & 9 & 11 & \\
\hline Coccinellidae & Unidentified larva & $*$ & 8 & 16 & 5 & 9 & \\
\hline Histeridae & Saprinus sp. & LeConte & 11 & 4 & 7 & 5 & \\
\hline Carabidae & Harpalus pennsylvanicus & Dejean & 3 & 2 & 9 & 8 & \\
\hline Carabidae & Amara latior & Kirby & 7 & 5 & 6 & 6 & \\
\hline Gryllidae & Gryllus sp. & Linnaeus & 1 & 1 & 10 & 16 & \\
\hline Gastropoda & Agriolimax reticulatus & Muller & 8 & 6 & 3 & 4 & \\
\hline Elateridae & Agriotella sp. & $*$ & 3 & 1 & 6 & 11 & \\
\hline Tenebrionidae & Coniontis puncticollis & LeConte & 3 & 4 & 0 & 8 & \\
\hline Noctuidae & Unidentified Larva & $*$ & 3 & 4 & 2 & 3 & \\
\hline Elateridae & Horistonotus inanus & LeConte & 2 & 0 & 6 & 2 & \\
\hline Scarabaeidae & Aphodius pardalis & LeConte & 3 & 2 & 5 & 3 & \\
\hline Curculionidae & Pantomorus cervinus & Boheman & 2 & 2 & 3 & 3 & \\
\hline Carabidae & Unidentified larva & $*$ & 5 & 1 & 1 & 3 & \\
\hline Latridiidae & Unidentified & $*$ & 1 & 0 & 5 & 1 & \\
\hline Carabidae & Tachys inornata & LeConte & 1 & 1 & 0 & 3 & \\
\hline Carabidae & Pterostichus sp. & LeConte & 0 & 1 & 3 & 5 & \\
\hline Carabidae & Anisodactylus californiacus & Dejean & 0 & 1 & 3 & 2 & \\
\hline Carabidae & Platynus punctiformis & Say & 0 & 2 & 1 & 7 & \\
\hline Tenebrionidae & Eleodes sp. & LeConte & 1 & 1 & 1 & 2 & \\
\hline
\end{tabular}




$\begin{array}{lllllll}\text { Lathridiidae } & \text { Melanophthalma sp. } & \text { LeConte } & 0 & 0 & 0 & 6 \\ \text { Chrysomelidae } & \text { Chaetocnema repens } & \text { McCrea } & 0 & 0 & 1 & 4 \\ \text { Carabidae } & \text { Unidentified } & * & 1 & 1 & 3 & 0 \\ \text { Cryptophagidae Atomaria sp. } & \text { Stephens } & 0 & 0 & 1 & 2 \\ \text { Carabidae } & \text { Tachys sp. } & \text { Stephens } & 0 & 1 & 1 & 2 \\ \text { Carabidae } & \text { Unidentified } & * & 0 & 1 & 2 & 1 \\ \text { Tenebrionidae } & \text { Notibius puncticollis } & \text { LeConte } & 1 & 0 & 0 & 1 \\ \text { Histeridae } & \text { Unidentified } & * & 0 & 1 & 0 & 1 \\ \text { Carabidae } & \text { Notiophilus sylvaticus } & \text { Eschscholtz } & 0 & 0 & 0 & 2 \\ \text { Carabidae } & \text { Chlaenius tricolor } & \text { Chaudoir } & 0 & 0 & 0 & 0 \\ \text { Carabidae } & \text { Harpalus fraternus } & \text { LeConte } & 0 & 0 & 1 & 1 \\ \text { Carabidae } & \text { Stenolophus californicus } & \text { LeConte } & 0 & 0 & 0 & 2 \\ \text { Mutilidae } & \text { Dasymutilla aureola pacificaCresson } & 0 & 0 & 0 & 2 \\ \text { Carabidae } & \text { Tachys sp. } & \text { LeConte } & 0 & 0 & 1 & 0 \\ \text { Scarabaeidae } & \text { Unidentified } & * & 0 & 0 & 0 & 0 \\ \text { Scarabaeidae } & \text { Aphodius rubripennis } & \text { Horn } & 0 & 0 & 0 & 0 \\ \text { Carabidae } & \text { Amara insignis } & \text { Dejean } & 0 & 0 & 0 & 1 \\ \text { Tenebrionidae } & \text { Tribolium confusum } & \text { Jaquelin Du Val } & 0 & 0 & 0 & 1 \\ \text { Carabidae } & \text { Acupalpus limbaris } & \text { LeConte } & 0 & 0 & 0 & 1 \\ \text { Carabidae } & \text { Tachys laevus } & \text { LeConte } & 0 & 0 & 0 & 0 \\ \text { Carabidae } & \text { Tachys incurva } & \text { LeConte } & 0 & 0 & 0 & 1 \\ * \text { Organism not identified to species } & & & & & & \end{array}$


